Poznańskie Studia Teologiczne 30(2016), s. 285-323.

doi: $10.14746 /$ pst.2016.30.14

Norbert Podhorecki ${ }^{1}$

Wyższe Seminarium Duchowne w Przemyślu

\title{
Dialogiczna otwartość teologii kardynała Waltera Kaspera w nurcie dziedzictwa katolickiej szkoły tybingeńskiej
}

Stwierdzenie, że w kształtowaniu naszego sposobu myślenia oraz poglądów, którym hołdujemy, ogromną rolę odgrywają mistrzowie, u boku których wzrastaliśmy, i określone środowiska, które wielopłaszczyznowo formowały nie tylko naszą świadomość, ale nawet metodykę naszego rozumowania i działania jest właściwie truizmem. Nie inaczej sprawy się mają z wielkimi myślicielami i wizjonerami. Także oni mają swój punkt odniesienia, horyzont ideowy, fundament, na którym budują gmach swojego dorobku. Prawdę tę w odniesieniu do środowiska teologicznego potwierdza znany polski dogmatyk o. Stanisław C. Napiórkowski, zwracając uwagę na powszechność i niejako „nieuchronność” owego zjawiska².

Walter Kasper, wieloletni profesor teologii dogmatycznej na uniwersytetach w Münster i Tybindze, biskup diecezji Rottenburg-Stuttgart (1989-1999), przewodniczący Papieskiej Rady ds. Popierania Jedności Chrześcijan i Komisji ds. Religijnych Kontaktów z Judaizmem (2001-2010), a od roku 2001 kardynał, nie jest tutaj wyjątkiem. W jego przypadku ogromną rolę odegrał związek z myślą i dziedzictwem teologicznym katolickiej szkoły w Tybindze, cenionego w Niemczech ośrodka teologii obu wyznań. Wypada zgodzić się ze zdaniem, które formułuje Grzegorz Bubel, że:

\footnotetext{
${ }^{1}$ Ksiądz Norbert Podhorecki, dr teologii (ur. 1966 r., Lublin), studia teologiczne w Przemyślu i na Uniwersytecie im. Jana Gutenberga w Moguncji (Niemcy). Wykładowca filozofii i teologii w Wyższym Seminarium Duchownym w Przemyślu. Obszary zainteresowań: hermeneutyka dogmatu, filozofia kultury, współczesny fundamentalizm i relatywizm.

${ }^{2}$ S.C. Napiórkowski, Jak uprawiać teologię, Wrocław 1996², s. 31, 42-44. Napiórkowski pisze: „Szkoły teologiczne istniały już w starożytności (Antiocheńska i Aleksandryjska). [...] W teologii współczesnej podziały przebiegają raczej regionami i środowiskami. [...] teologowi z formacją scholastyczną niezmiernie trudno przestawić się na teologię historiozbawczą; studia historyczne skłaniają teologa do teologii raczej pozytywnej niż spekulatywnej, natomiast specjalizacja w zakresie filologii biblijnej prowadzi go do teologii typu hermeneutycznego; na ogół absolwenci uczelni rzymskich bardziej cenią dokumenty Magisterium Kościoła niż absolwenci kościelnych uczelni niemieckich czy amerykańskich itd. Wreszcie decyzje na pozór obojętne pod względem teologicznym, a nawet tzw. przypadki (np. wstąpienie do dominikanów czy franciszkanów) praktycznie rozstrzyga o przyszłych sympatiach pro-Tomaszowych czy pro-Bonawenturiańskich".
} 
w swoich pracach Kasper wielokrotnie powoływał się na swój duchowy związek z założeniami katolickiej szkoły w Tybindze, uważając ją za wzór przywiązania do kościelnej tradycji i jednocześnie otwarcia na dialog ze współczesnym światem. Nic więc dziwnego, że teologia Kaspera jest postrzegana przez wielu jako posoborowe ukoronowanie katolickiej szkoły Tybingi ${ }^{3}$.

Zdanie to potwierdzają także inni znawcy zagadnienia, podkreślając, że niemiecki kardynał nie tylko zewnętrznie zaliczany jest w poczet zasłużonych teologów o rodowodzie tybingeńskim, ale przynależy do nich duchem, metodologią oraz spojrzeniem na Kościół i jego misję głoszenia Chrystusa współczesnemu światu4 .

Sam zaś Walter Kasper pisze:

Katolicka szkoła tybingeńska, z której sam się wywodzę, będąc kontynuatorem jej ducha i zasad, charakteryzuje się płodnym napięciem i wzajemnym przenikaniem trzech fundamentalnych dla niej pryncypiów: naukowości, kościelności i praktycznie zorientowanej otwartości. Jestem przekonany, że owe trzy zasady, szczególnie w obecnej sytuacji przełomu w teologii i Kościele, nic nie straciły ze swej aktualności i znaczenia ${ }^{5}$.

Oczywiście dziedzictwo Tybingi nie jest jedynym nurtem myślowym kształtującym teologiczno-kościelną aktywność kardynała Kaspera. Należałoby wspomnieć na tym miejscu chociażby o jego pogłębionych studiach nad myślą fillozoficzno-teologiczną Friedricha W.J. Schellinga, wybitnego przedstawiciela klasycznego niemieckiego idealizmu, których wynikiem była praca habilitacyjna Kaspera Das Absolute in der Geschichte ${ }^{6}$. Jest ona przykładem jego otwartości na filozoficzne idee wyrażające i kształtujące duchowy rozwój kolejnych epok. Ta otwartość zaowocowała w późniejszych jego dziełach dowartościowaniem znaczenia procesów dziejowych i realizującej się w nich ludzkiej wolności w odniesieniu do łaski objawiającego się w historii Boga. Najwyższym wyrazem ich wzajemnego współistnienia i oddziaływania staje się osoba Jezusa Chrystusa, będąca pośrednikiem boskiego Absolutu w ludzkiej historii (concretum universale) i ostatecznym odniesieniem wszelkiej ludzkiej wolności .

${ }^{3}$ G. Bubel, Walter Kasper. Między tradycja a nowoczesnościa, w: Leksykon wielkich teologów XX/XXI wieku, red. J. Majewski, J. Makowski, Warszawa 2003, s. 149-150.

${ }^{4}$ Por. W.P. Loewe, The New Catholic Tübingen Theology of Walter Kasper: Foundational Issues, „Heythrop Journal” 21(1980), s. 30-32; A. Nichols, Walter Kasper and His Theological Programme, „New Blackfriars” 1(1986), s. 16-18; N. Madonia, Ermeneutica e cristologia in Walter Kasper, Palermo 1990, s. 47-62.

${ }^{5}$ W. Kasper, Ansprache beim Empfang des Katholisch-Theologischen Fakultätentages (27 Januar 1991), „Theologische Quartalschrift“ 171(1991), nr 4 [odtąd skrót: Ansprache], s. 250; por. tenże, Karl Adam. Zu seinem 100. Geburtstag und 10. Todestag, „Theologische Quartalschrift” 156(1976), nr 4 [odtąd skrót: Karl Adam], s. 258.

${ }^{6}$ W. Kasper, Das Absolute in der Geschichte. Philosophie und Theologie der Geschichte in der Spätphilosophie Schellings, Mainz 1965.

${ }^{7}$ Por. N. Podhorecki, Das Absolute in der Geschichte. Koncepcja Objawienia wedtug Waltera Kaspera, w: Objawienie Boże w interpretacji wspótczesnych teologów, Studia Theologiae Funda- 
Zebrany i przedstawiony na tym miejscu materiał będzie miał za zadanie ukazanie ścisłego związku sposobu uprawiania teologii przez niemieckiego kardynała $\mathrm{z}$ jedną zaledwie fundamentalną zasadą, jaką kierowała się XIX-wieczna katolicka szkoła w Tybindze, mianowicie praktycznie zorientowaną otwartością wobec zagadnień współczesności. Pryncypia teologii tybingeńczyków kształtowały myśl i dzieło Kaspera przez wszystkie lata jego działalności naukowej i duszpasterskiej. Ukażemy to na podstawie odwołania do jego wczesnych dzieł oraz do najnowszej publikacji, która nawiasem mówiąc, z innego niż pryncypia tybingeńskie powodu, wzbudziła spore zainteresowane, ale i nie mniejsze kontrowersje, wśród wiernych i pasterzy Kościoła katolickiego ${ }^{8}$.

\section{Katolicka szkoła w Tybindze i jej teologiczne pryncypia}

Za początek katolickiej szkoły teologicznej w niemieckiej Tybindze uważa się założenie w 1812 roku Katholische Landesuniversität, uniwersytetu teologicznego w Ellwangen, miasteczku niemal w całości katolickim i w niewielkim stopniu zarażonym panującym podówczas powszechnie duchem oświeceniowym. Był to z początku nie tyle właściwy, autentyczny uniwersytet, ile raczej szkoła teologiczna, nastawiona prawie w całości na przygotowywanie kandydatów do kapłaństwa na terenie Wirtembergii. Przeniesienie wydziału w roku 1817 do Tybingi, miasta ze znaczną przewagą protestantów, oznaczało pojawienie się możliwości poszerzenia horyzontów w dialogu międzywyznaniowym i międzykulturowym oraz wzrost znaczenia i pogłębienie myśli teologicznej szkoły9 .

Do najważniejszych postaci szkoły tybingeńskiej należą: Johann Sebastian von Drey (1777-1853), Johann Baptist Hirscher (1788-1865), Johann Adam Möhler (1796-1838), Franz Anton Staudenmaier (1800-1856) oraz Johann Evangelist von Kuhn (1806-1887). „Ponowne odkrycie katolickiej szkoły tybingeńskiej XIX wieku wraz z pogłębioną analizą jej dziedzictwa, szczególnie w odniesieniu do dzieł Johanna Adama Möhlera, przyczyniły się w sposób rozstrzygający do

mentalis t. 1, red. B. Kochaniewicz, Poznań 2010, s. 209-236, tenże, Jezus Chrystus jako concretum universale w myśli teologicznej Waltera Kaspera, w: Jezus Chrystus w refleksji współczesnych teologów, red. B. Kochaniewicz, Colloquia Disputationes 21, Poznań 2013, s. 75-93.

${ }^{8}$ Chodzi o książkę Waltera Kaspera Miłosierdzie. Klucz do chrześcijańskiego życia, tłum. R. Zajączkowski, Poznań 2014 [odtąd skrót: Miłosierdzie], w oryginale: W. Kasper, Barmherzigkeit. Grundbegriff des Evangeliums - Schlüssel christlichen Lebens, Freiburg im Breisgau 2013. Znajdującą się w niej tezę o potrzebie uwzględnienia „przestrzeni miłosierdzia” (s. 197 w wersji pol.) w odniesieniu do osób rozwiedzionych, a pragnących dostępu do sakramentów świętych, można pogłębić przez lekturę tekstu Kardynat Walter Kasper o udzielaniu komunii dla osób rozwiedzionych, http://tygodnik.onet.pl/wwwylacznie/przeczytaj-cale-przemowienie-kard-kaspera-ktore-wy wolalo-burze-w-watykanie/xtrbr [dostęp: 16.03.2015].

${ }^{9}$ Por. P. Colombo, Szkoła tybingeńska, w: Historia teologii, t. 4: Epoka nowożytna, red. G. Angelini, G. Colombo, M. Vergottini, thum. W. Szymona, Kraków 2008 [odtąd skrót: Szkoła tybingeńska], s. 296. 
odnowy teologii i Kościoła w naszym stuleciu”, napisał Walter Kasper w słowie wstępnym do pracy Offenbarung und Geschichte Roberta Cornelissena ${ }^{10}$.

Oczywiście szczegółowe przedstawienie i charakterystyka szkoły tybingeńskiej przerastałyby ramy tego opracowania. Znaleźć je można przede wszystkim w publikacjach Josefa R. Geiselmanna ${ }^{11}$.

Paolo Colombo w opracowaniu dotyczącym dorobku katolickich teologów z XIX-wiecznej Tybingi ${ }^{12}$ zauważa, że chociaż próby sprowadzenia całego dziedzictwa szkoły do monotematycznej jedności niosą ze sobą ryzyko niedozwolonych uproszczeń i lekceważenia oryginalności i wkładu poszczególnych postaci, to możliwe okazuje się ukazanie pewnych linii syntetycznych, pozwalających mówić o wspólnym dla nich sposobie wyrażania własnych idei. Rozmaite elementy ich dorobku, a nawet sposób rozmieszczania akcentów znajdują podstawowy łączący je wątek w podkreślaniu historycznego wymiaru badan teologicznych ${ }^{13}$. „Można się w tym dopatrzyć wyraźnych analogii do ówczesnej refleksji filozoficznej, w której determinującym zjawiskiem wydaje się zwłaszcza wpływ spekulatywnego idealizmu Hegla; w jego optyce bardziej pierwotny charakter ma nie sama prawda, lecz historia: w ostatecznej analizie między prawdą i historią zachodzi ścisła koherencja"14.

Colombo rozwija tę refleksję, zaznaczając, że kolejnymi charakterystycznymi cechami sposobu uprawiania teologii wśród tybingeńczyków były: dialog z teologicznym światem ewangelickim i związany z nim postulat otwarcia eku-

${ }^{10}$ R.J.F. Cornelissen, Offenbarung und Geschichte, Essen 1972, Geleitwort von W. Kasper, s. XIII.

${ }^{11}$ Zob. przede wszystkim: J.R. Geiselmann, Die katholische Tübinger Schule. Ihre theologische Eigenart, Freiburg im Breisgau 1964; Geist des Christentums und des Katholizismus, t. 5: Deutsche Klassiker der katholischen Theologie aus neuerer Zeit, Mainz 1940; Lebendiger Glaube aus geheiligter Überlieferung, Mainz 1942; Die Anthropologie J.A. Möhlers, Freiburg im Breisgau 1955; Die lebendige Überlieferung als Norm des christlichen Lebens, Freiburg im Breisgau 1959, oraz jego publikacje w „Theologische Quartalschrift“ 111(1930), s. 39-147; 115(1934), s. 83-140 i w wielu innych miejscach. Z okazji jubileuszu 150-lecia powstania katolickiej szkoły tybingeńskiej w jej czasopismie „Theologische Quartalschrift“ (ThQ 148 [1968]), ukazały się liczne publikacje jej poświęcone. Zob. także dzieło zbiorowe: Theologie im Wandel. Festschrift zum 150jährigen Bestehen der katholisch-theologischen Fakultät an der Universität Tübingen 1817-1967, red. J. Ratzinger, J. Neumann, München 1967.

${ }^{12} \mathrm{Nie}$ wchodzimy tutaj w dywagacje, czy uprawniona jest w ogóle nazwa Tübinger Schule w odniesieniu do różnych teologów Wydziału Teologicznego. Słyszy się bowiem opinie, jakoby nie odznaczali się oni taką zbieżnością poglądów i tożsamością metody, które uzasadniałaby w pełni użycie terminu „szkoła”. Niemniej jednak analiza dorobku teologów z Tybingi pozwala na przyporządkowanie ich do wspólnej grupy, nie tylko pod względem przynależności do tej samej uczelni czy ram czasowych ich działalności, ale także wspólnego im wszystkim pragnienia: odcięcia się od czysto polemicznego tonu teologii tamtych czasów, otwartości na dialog i nacisku na szukanie syntezy pomiędzy tradycją i dogmatem z jednej strony a procesami historycznymi i wyzwaniami współczesności z drugiej. Por. P. Colombo, Szkoła tybingeńska, s. 295-296.

${ }^{13}$ Por. tamże, s. 297-298.

${ }^{14}$ Tamże, s. 298. 
menicznego (pokłosie konfrontacji z wydziałem ewangelickim Tybingi, cieszącym się większą renomą za względu na tradycje historyczne i system organizacyjny), zasadnicze nawiązanie do współczesnej filozofii idealistycznej (oprócz Hegla chodzi tu także o niemały wpływ Schellinga), przekazywanie wiary i tradycji Kościoła w dialogu z myślą nowożytną (stała konfrontacja z duchem czasu), pluralizm poglądów i wypowiedzi, krytyczny dialog z Rzymem i wreszcie podkreślanie historycznego wymiaru badań teologicznych ${ }^{15}$.

Dla potrzeb naszego opracowania, przy jednoczesnym odwołaniu do publikacji samego Waltera Kaspera, należałoby tę charakterystykę nieco usystematyzować. Do wspomnianych już wyżej przez niego trzech zasad, leżących u podstaw teologicznego dziedzictwa teologów szkoły tybingeńskiej, mianowicie: praktyczno-pastoralnego otwarcia i zorientowania na zagadnienia współczesności, naukowości i wierności tradycji Kościoła ${ }^{16}$, należałoby dodać czwarty, bardzo istotny dla teologów z Tybingi motyw, mianowicie wspomnianą wyżej, dobrze pojętą historyczność teologii. Także ta czwarta zasada, a może nawet w szczególności ona, zajmuje w dziełach kardynała Kaspera pozycję eksponowaną ${ }^{17}$.

Chociaż bezpośrednie omówienie dokonań teologów z Tybingi znajdujemy u Kaspera na jednym zaledwie miejscu, gdzie wprost charakteryzuje on ducha szkoły, jej pryncypia teologiczne oraz osiagnięcia i recepcję myśli jej przedstawicieli ${ }^{18}$, to jej dziedzictwo, metodologię i idee przewodnie odnajdujemy w bardzo wielu jego wypowiedziach i publikacjach. Zauważamy nieustanną ich obecność w pogłębionej refleksji teologicznej Kaspera i unaocznieniu jej rezultatów czytelnikowi ${ }^{19}$.

\section{Praktycznie zorientowana otwartość teologii na zagadnienia współczesności}

Podobnie jak z niemożnością przedstawienia na tym miejscu dogłębnej analizy i całościowej oceny dokonań teologów z Tybingi, rzecz się ma niestety z wyczerpującym zobrazowaniem obecności wszystkich czterech wymienio-

\footnotetext{
${ }^{15}$ Por. tamże, s. 296-300.

${ }^{16}$ W. Kasper, Ansprache, s. 250; tenże, Karl Adam, s. 258.

${ }^{17}$ Tenże, Die Methoden der Dogmatik. Einheit und Vielheit, München 1967 [odtąd skrót: Die Methoden], s. 26, 30; tenże, Verständnis der Theologie damals und heute, w: tenże, Glaube und Geschichte, Mainz 1970 [odtąd skrót: Verständnis], s. 14-20; J. Morawa, Die Communio-Kirche als Sakrament des Heils in und für die Welt. Zum erneuerten Verständnis der Sendung der Kirche in der Gegenwart im Werk Walter Kaspers, Frankfurt am Main 1996 [odtąd skrót: Die Communio-Kirche], s. 56.

${ }^{18}$ Por. W. Kasper, Verständnis, s. 9-32.

${ }_{19}$ Por. tenże, Jezus Chrystus, tłum. B. Białecki, Warszawa 1983, s. 5-6; tenże, Bóg Jezusa Chrystusa, thum. J. Tyrawa, Wrocław 1996 [odtąd skrót: Bóg Jezusa Chrystusa], s. 5; J. Morawa, Die Communio-Kirche, s. 149.
} 
nych pryncypiów ich szkoły w dziele kardynała Kaspera. Z uwagi na ograniczoność miejsca skoncentrujemy naszą uwagę na pierwszej i istotnej dla teologii naszych czasów zasadzie praktycznej otwartości na zagadnienia i problemy współczesności.

Jest to bez wątpienia istotny motyw twórczości tybingeńczyków, który wyraźnie zaznacza swą obecność w dziele Waltera Kaspera ${ }^{20}$. Jak zauważa niemiecki teolog, chociaż w ostatnich latach obserwujemy pewne zniekształcenia i nadużycia wobec tej normy w myśli i życiu Kościoła, to przecież sama jej zasadność nie powinna podlegać dyskusji ${ }^{21}$. „Cecha wyróżniająca XIX-wiecznych teologów z Tybingi, jaką jest odważne otwarcie na duchowe prądy epoki”’22, pozostaje aktualna także dla nas i teologii naszych czasów, pisze Kasper.

Wypada przy tym zaznaczyć, że zasada owa jest w dużym stopniu reprezentatywna dla całości jego dorobku i daje dokładny obraz zarówno myśli teologicznej Kaspera, jak i dziedzictwa, do którego nawiązuje.

Przedstawiając myśl teologiczną niemieckiego kardynała, jako nawiązująca do pryncypium szkoły tybingeńskiej i podejmującą się jej kontynuacji we współczesnych realiach, posłużymy się określonym schematem ${ }^{23}$. Po krótkim scharakteryzowaniu zasady otwartości i podkreśleniu jej aktualności, szczególnie z punktu widzenia Kaspera, przedstawimy następnie jej konsekwentne odzwierciedlenie w jego poglądach oraz wypowiedziach. Walter Kasper nie tylko potwierdza występowanie tej cechy w teologii szkoły tybingeńskiej, dostrzegając potrzebę jej kontynuacji w naszych czasach, ale także świadomie ją podejmuje, co z kolei znajduje szerokie odbicie w jego myśli teologicznej.

W naszej analizie odwołamy się zarówno do początkowych publikacji Kaspera, jak i do ostatniego jego dzieła, o którym była już mowa wyżej. Pozwoli nam to uchwycić historyczną i metodologiczną perspektywę, jak i potwierdzić stałość i niezmienność zasadniczej więzi myśli niemieckiego teologa z dziedzictwem katolickiej szkoły w Tybindze.

\subsection{Istota zasady otwartości na duchowe prądy epoki}

Praktycznie zorientowana otwartość na panoramę myśli współczesnej została przejęta przez teologów z Tybingi za dziedzictwo wielkiej szkoły augustyńsko-franciszkańskiej oraz średniowiecznej tradycji tomistycznej, pisze Walter

\footnotetext{
${ }^{20}$ Por. W. Kasper, Die Methoden, s. 10; tenże, Verkündigung als Provokation, w: tenże, Glaube und Geschichte, Mainz 1970, s. 237; tenże, Zur gegenwärtigen Situation und zu den gegenwärtigen Aufgaben der systematischen Theologie, w: tenże, Theologie und Kirche, Mainz 1987 [odtąd skrót: Zur Situation], s. 18-20.

${ }^{21}$ Por. tenże, Zur Situation, s. 18.

${ }^{22}$ Tenże, Verständnis, s. 9-10.

${ }^{23}$ Schemat ten nawiązuje do mojej publikacji: N. Podhorecki, Offenbarung - Schrift - Tradition. Walter Kaspers Beitrag zum Problem der Dogmenhermeneutik, Frankfurt am Main 2001.
} 
Kasper $^{24}$. Stała się ona także na owe czasy godną uwagi alternatywą wobec restauratywno-konserwatywnych kierunków XIX-wiecznej teologiii ${ }^{25}$. Przedstawiciele szkoły tybingeńskiej wykazali się niemałą na owe czasy odwagą w uprawianiu teologii $\mathrm{w}$ kontekście i świadomości historycznych przemian oraz procesów, przy jednoczesnym podjęciu wyzwania, rzuconego myśli katolickiej przez współczesne prądy filozoficzne ${ }^{26}$. Co ciekawe, ten właśnie styl został przejęty przez ojców soborowych Vaticanum Secundum. To właśnie on cechował soborową wizję kultury, odnowy, dialogu i ekumenizmu oraz późniejszą egzegezę nauczania Soboru w duchu hermeneutyki reformy. Soborowa Konstytucja pastoralna Gaudium et spes o Kościele w świecie współczesnym jest, według Kaspera, najlepszym przykładem tego właśnie procesu ${ }^{27}$. Kościół epoki soborowej podjął się także, roztropnie wprawdzie, ale jednoznacznie, recepcji nowożytnych idei wolności, równości i braterstwa, dostrzegając w nich współczesne ucieleśnienie wiecznie żywego dziedzictwa kultury i ducha chrześcijańskiego ${ }^{28}$.

Otwartość teologów z Tybingi nie była wynikiem powierzchownego i krótkowzrocznego pragnienia dostosowania się do wymogów ducha czasu, lecz wypływała z żywego ducha najlepszej tradycji chrześcijańskiej ${ }^{29}$. Kontynuując tę myśl, Kasper cytuje jednego z tybingeńczyków, Johanna Sebastiana Drey:

Nie powinniśmy się dziwić, jeśli w procesie dokładnej analizy zaobserwujemy zdumiewającą zbieżność dziejów politycznych i horyzontów myślowych określonego narodu. Stan jego nauki i kultury nie jest przecież niczym innym, jak idealistycznym wyrazem drzemiącego $\mathrm{w}$ nim wielorakiego potencjału. Byłoby zatem rzeczą możliwą i ze wszech miar interesująca, podjać się analizy dokonań naszego [niemieckiego] narodu na polu teologii, paralelnie do jego całej historii, aby dopiero na podstawie takiego odniesienia właściwie pojąc i ocenić obie te wielkości ${ }^{30}$.

Ów duch żywej tradycji krystalizującej się w teraźniejszości przepaja całą myśl teologiczną tybingeńczyków, stwierdza Walter Kasper ${ }^{31}$. Świeżość i dojrzałość ich optyki partycypowała w atmosferze duchowego przełomu tamtych czasów. Kwestią dyskusyjną pozostaje, jak stwierdza kardynał, czy aktywność teo-

\footnotetext{
${ }^{24}$ Por. tenże, Sie suchten die Wahrheit. Heilige Theologen, Mainz 1985, s. 12-16; tenże, Zur Situation, s. 18; tenże, Die Wissenschaftspraxis der Theologie, w: Handbuch der Fundamentaltheologie, t. 4, red. W. Kern, H.J. Pottmeyer, M. Seckler, Freiburg 1988 [odtąd skrót: Die Wissenschaftspraxis], s. 246.

${ }^{25}$ Por. J. Morawa, Die Communio-Kirche, s. 66.

${ }^{26}$ Por. W. Kasper, Verständnis der Theologie, s. 9-14.

${ }^{27}$ Por. tenże, Zur Situation, s. 18.

${ }^{28}$ Por. tenże, Verständnis der Theologie, s. 12.

${ }^{29}$ Por. tamże, s. 10.

${ }^{30}$ J.S. Drey, Revision des gegenwärtigen Zustandes der Theologie, w: Geist des Christentums und des Katholizismus, red. J.R. Geiselmann, Mainz 1940, s. 85, cyt. za W. Kasper, Verständnis der Theologie, s. 10.

${ }^{31}$ Por. W. Kasper, Verständnis der Theologie, s. 10.
} 
logów z Tybingi potrafiła sprostać wysokiemu poziomowi myśli filozoficznej swej epoki, a ich dialog z dziedzictwem niemieckiego idealizmu był wystarczająco wyrafinowany, niemniej jednak niezaprzeczalne pozostaje nowatorstwo ich wysiłku intelektualnego na tle czysto negatywnej polemiki i apologetyki teologicznej tamtych czasów ${ }^{32}$.

Tybingeńczycy nie odnosili się bezkrytycznie do osiagnięć myśli filozoficznej swojej epoki. Wprost przeciwnie, ich pisma pełne są zastrzeżeń czy wręcz krytyki.

Tym niemniej chodzi zawsze o krytykę twórcza, która pogłębia dialog i potrafi ze zdumiewającą przenikliwością ducha wszystko to, co wartościowe, dostrzec i podnieść na wyższy poziom. Idea dialogu i odczytywania znaków czasu stała się reguła postępowania tybingeńczyków na długo przedtem, zanim przyjęto ją i uprawomocniono, a nawet w pewien sposób sfatygowano w Kościele epoki soborowej ${ }^{33}$.

Oczywiście istnieją poważne różnice pomiędzy światem teologów z Tybingi XIX wieku a naszymi czasami. Można wręcz odnieść wrażenie, że oprócz dążenia do dialogu ze współczesną myślą i kulturą niewiele nas ze sobą łączy ${ }^{34}$. Tybingeńczycy byli świadkami epokowego przełomu i ,rozkwitu idealizmu ducha w pełnym znaczeniu tego słowa" ${ }^{35}$. Dzisiaj natomiast pozostajemy pod wpływem nie tyle idei, ile raczej pragmatycznej analizy suchych faktów. Wówczas podejmowano ambitne próby ogarnięcia całości rzeczywistości w jednym, spójnym myślowo i pojęciowo, systemie. Usiłowano ująć metodycznie całość doświadczenia i myśli w układzie definicji i kategorii, czego ewidentnym przykładem stała się choćby filozofia Hegla. Dzisiaj, z perspektywy czasu, odnosimy się do tych idealistycznych prób z daleko posuniętym sceptycyzmem. Nasza wiedza o otaczającym świecie pomnożyła się do tego stopnia, że współcześnie nikt nie może uzurpować sobie prawa do ogarnięcia jej i przedstawienia za pomoca jednego zintegrowanego systemu ${ }^{36}$.

Różnice sięgają nawet jeszcze głębiej, pisze Kasper. Teologowie z Tybingi zwrócili się bowiem energicznie i polemicznie przeciwko dziedzictwu oświeceniowemu.

Opierając się na romantycznej definicji wspólnoty i tradycji skierowali ostrze krytyki przeciwko nowożytnemu duchowi autonomii; wychodząc zaś z romantycznego pojęcia zasady życia - centralnej koncepcji pojmowania rzeczywistości przez myślicieli owej epoki - odnieśli się krytycznie do fundamentów refleksji filozoficznej Kartezjusza. Byli przekonani, że wraz z nimi oświecenie odchodzi ze sceny dziejów w mrok niepamięci ${ }^{37}$.

\footnotetext{
${ }^{32}$ Por. W. Kasper, Verständnis der Theologie, s. 10.

${ }^{33}$ Tamże, s. 11.

${ }^{34}$ Por. tamże.

${ }^{35}$ Tamże.

${ }^{36}$ Por. tamże.

${ }^{37}$ Tamże, s. 12
} 
Tymczasem dla nas, po tylu latach, oświecenie i jego konsekwencje wcale nie odeszły w przeszłość, lecz stają się wciąż na nowo poważnym wyzwaniem ${ }^{38}$.

Ponad wszystkimi tymi różnicami potrafimy jednak dostrzec głęboką więź pomiędzy współczesnością a epoką myśli idealistyczno-romantycznej i oświeceniem, zauważa Kasper ${ }^{39}$. Chodzi mianowicie o odniesienie i samorealizację człowieka w jego świecie. Prawdziwe odnalezienie się jednostki w jej środowisku i społeczności, której realizację niemiecki idealizm upatrywał na drodze spekulatywnego pojęciowania, a Karol Marks proklamował jako humanizację świata poprzez proces pracy, upatruje się dzisiaj w zastosowaniu zaawansowanej techniki oraz na drodze planowania, sterowania i daleko idącej manipulacji wobec świata przyrody i ingerencji w procesy społeczne i kulturowe ${ }^{40}$. Biorąc zatem pod uwagę tę epokową więź, łączącą nas z duchem początków XIX stulecia, nawiązanie do zasad teologicznych szkoły tybingeńskiej wydaje się przedsięwzięciem wielce obiecującym ${ }^{41}$. Zasada ta dotyczyć będzie z pewnością ich otwartości na wyzwania współczesności i jej myśli filozoficzno-teologicznej.

\subsection{Potrzeba kontynuacji zasady otwartości w teologii}

Kasper jest świadomy wymagań stawianych refleksji teologicznej. Dzisiaj, tak jak zawsze, człowiek domaga się, aby w procesie racjonalnej i metodycznej analizy wypracowała ona takie rozumienie i sposób proklamacji wiary, który przynosiłby mu odpowiedzi na jego pytania dotyczące sensu i celu rzeczywistości teraźniejszej i nadziei przyszłego świata ${ }^{42}$. To zadanie stawiane teologii wymaga, aby wzniosła się ona ponad dyletancki i powierzchowny sposób myślenia, co z kolei pozwoli jej utrzymać określony poziom naukowy i nie stracić z oczu szerokiego horyzontu zagadnień i zadań, które niesie ze sobą współczesność ${ }^{43}$. Stąd właśnie, jak konstatuje Walter Kasper, tybingeńska zasada otwartości teologii na wyzwania epoki ma i dzisiaj ogromne znaczenie ${ }^{44}$.

Spekulacja teologiczna nie powinna zamykać się w swoim hermetycznym środowisku. Musimy ją raczej postrzegać w kontekście określonej odpowiedzialności w zakresie społeczno-kulturowym. „Jej miejsce to nie tylko dyskurs akademicki, ale również szeroka scena kościelnego i społecznego oddziaływania" ${ }^{45}$. Praktyczny wymiar życia Kościoła stawia wciąż na nowo przed każdym pokole-

${ }^{38}$ Por. tamże.

${ }^{39}$ Por. tamże, s. 13.

${ }^{40}$ Por. tamże.

${ }^{41}$ Por. tamże.

${ }^{42}$ Por. tenże, Die Wissenschaftspraxis, s. 246.

${ }^{43}$ Por. tenże, Die Methoden, s. 10; tenże, Bóg Jezusa Chrystusa, s. 9-10; J. Morawa, Die Communio-Kirche, s. 66.

${ }^{44}$ Por. W. Kasper, Verständnis der Theologie, s. 9, tenże, Zur Situation, s. 18-20.

${ }^{45}$ Tenże, Zur Situation, s. 19. 
niem teologów wymóg wypracowania konkretnego sposobu urzeczywistniania wiary, nadziei i miłości, a przez to stałej odnowy duchowego i mistycznego wymiaru teologii ${ }^{46}$.

Podobnie serio należy podchodzić do zadań teologii wobec świata. Praktycznie zorientowana teologia powinna nie tylko postrzegać całą rzeczywistość w świetle Ewangelii, ale także pogłębiać znajomość Dobrej Nowiny w perspektywie „proroctwa” świata i tego, czym może on nas ubogacićc ${ }^{47}$. W dziele wypracowania takiej otwartości i dobrze pojętej katolickości i uniwersalizmu teologii niezbędny jest dialog z teologami bratnich Kościołów, ale także opcja fundamentalnej otwartości na problemy współczesności ${ }^{48}$.

Kasper proponuje zatem pewien teoretyczno-pragmatyczny model teologii, który sam nazywa „drogą chrześcijańskiej odpowiedzialności”49 , a który według niego koresponduje z wizją Soboru Watykańskiego II, usiłującego kroczyć szlakiem pośrednim pomiędzy przebrzmiałym, tradycjonalistycznym integryzmem i współczesnym, funkcjonalistycznym pojmowaniem roli Kościoła w społeczeństwie $^{50}$. „W takiej perspektywie zadanie teologii będzie polegać na wytyczaniu Kościołowi konkretnych dróg, w jaki sposób ma się on stawać dzisiaj uniwersalnym sakramentem zbawienia w świecie i dla świata"s5.

Tak więc, konstatuje Kasper, także w naszych czasach, za przykładem teologów katolickiej szkoły tybingeńskiej XIX wieku, musimy dla dobra teologii i Kościoła niestrudzenie odpowiadać na pytania współczesności i nawiązywać $\mathrm{z}$ nią intelektualny dialog.

\subsection{Realizacja zasady praktycznie zorientowanej otwartości teologii w dziele Waltera Kaspera}

Teza o konieczności otwartości teologii na dialog ze współczesnością i jej ideami uwidacznia się konsekwentnie w dziełach Kaspera, znajdując w nich poczesne miejsce. $\mathrm{Z}$ uwagi na oczywiste ograniczenia miejsca skoncentrujemy się na skrótowym przedstawieniu dwu zasadniczych wymiarów tej otwartości. Chodzi o praktyczne zorientowanie teologii Waltera Kaspera w służbie życia i wiary Kościoła oraz jej dialogiczną otwartość na współczesny świat. Przedstawienie to uzupełnimy, nawiązując do ostatnio opublikowanego dzieła niemieckiego teologa Miłosierdzie. Klucz do chrześcijańskiego życia.

${ }^{46}$ Por. W. Kasper, Zur Situation, s. 19; tenże, Sie suchten die Wahrheit. Heilige Theologen, Mainz 1985, s. 7-16.

${ }^{47}$ Por. tenże, Zur Situation, s. 19.

${ }^{48}$ Por. tamże.

49 Tamże.

${ }^{50}$ Por. tamże.

${ }^{51}$ Tamże.

${ }^{52}$ Tenże, Zur Situation, s. 18. 


\subsubsection{Praktyczne zorientowanie teologii w służbie życia i wiary współczesnego Kościoła}

„Konieczne zorientowanie praktyczne spekulacji teologicznej jest głęboko zakorzenione we wspólnocie wiary, życia, przepowiadania i liturgii Kościoła. Kościoła pojmowanego jak całość a także w różnorodności jego części. Jest ściśle z nim związane na sposób krytyczno-towarzyszący oraz pozytywno-inspirujący"52, pisze Walter Kasper. Prawdziwa teologia ma za zadanie nie tylko wypracowywać teoretyczno-spekulatywny wgląd w naturę swego przedmiotu, ale przede wszystkim orientować się na konkretną praxis wiary, nadziei i miłości ${ }^{53}$, a przez to uczestniczyć we wszystkich przejawach życia i działalności Kościoła.

a) Odpowiedzialność za kształt wiary i proces jej przekazywania

Kwestie istoty i wiarygodności wiary chrześcijańskiej, należące do kluczowych zagadnień teologii fundamentalnej, szczególnie w kontekście aspektu współczesnego modelu przekazu treści wiary (Rechenschaft vom Glauben heute), są dość szeroko omawiane w publikacjach przez Waltera Kaspera ${ }^{54}$. Można by nawet zaryzykować stwierdzenie, że zagadnienie odpowiedniego przekazu wiary przenika cała jego myśl teologiczną. Przekaz wiary, który w naszej strefie kulturowej i cywilizacyjnej napotyka od pewnego czasu spore problemy, musi się cechować zdolnością do otwartego dialogu, ale i misjonarską gorliwościąa Powinien on nawiązywać do sytuacji współczesnego człowieka, podejmować ludzkie problemy, być otwarty wobec krytycznych opinii i umożliwiać otwartą wymianę myśli. Musimy zdawać sobie sprawę, że chrześcijaństwo niezmiennie

\footnotetext{
${ }^{53}$ Por. tamże.

${ }^{54}$ Wymieńmy najistotniejsze publikacje: Der Glaube und die Gläubigen heute, „Militärseelsorge“ 10(1968), s. 208-221; Zum Problem der Rechtgläubigkeit in der Kirche von morgen, w: Kirchliche Lehre - Skepsis der Gläubigen, red. W. Kasper, F. Haarsma, F.X. Kaufmann, Freiburg im. Breisgau 1970, s. 37-96; Einführung in den Glauben, Mainz 1972; Die Zukunft des Glaubens, „Lebendige Seelsorge“ 1973, s. 14-19; Rechenschaft vom Glauben heute, „Universitas“ 28(1973), s. 1301-1307; Zukunft aus dem Glauben, Mainz 1978; Das Glaubensbekenntnis der Kirche, „Internationale katholische Zeitschrift Communio“ 13(1984), nr 3, s. 255-271; Die Weitergabe des Glaubens. Schwierigkeit und Notwendigkeit einer zeitgemäßen Glaubensvermittlung, w: Einführung in den Katholischen Erwachsenenkatechismus, red. W. Kasper, Düsseldorf 1985, s. 13-35; Tradierung und Vermittlung als systematisch-theologisches Problem, w: Tradierungskrise des Glaubens, red. E. Feifel, W. Kasper, München 1987, s. 30-52; Was alles Erkennen übersteigt, Freiburg 1987; Hinführen zum Glauben - warum und wie?, „Internationale katholische Zeitschrift Communio“ 17(1988), nr 2, s. 97-103. Wyczerpujące zestawienie znajdziemy w bibliografii Kaspera: J. Drumm, Bibliographie Walter Kasper 1960-1992, w: Dogma und Glaube. Bausteine für eine theologische Erkenntnislehre, red. E. Schockenhof, P. Walter, Mainz 1993, s. 294-333.

${ }^{55}$ Por. W. Kasper, Die Weitergabe des Glaubens. Schwierigkeit und Notwendigkeit einer zeitgemäßen Glaubensvermittlung, w: Einführung in den Katholischen Erwachsenenkatechismus, red. tenże, Düsseldorf 1985 [odtąd skrót: Die Weitergabe des Glaubens], s. 13; tenże, Einführung in den Glauben, Mainz 1972 [odtąd skrót: Einführung], s. 30.
} 
ma wiele do przekazania człowiekowi, który jest spragniony zbawienia, a przecież nie potrafi, mimo wielu prób, osiągnąć go, opierając się tylko na samym sobie $^{56}$.

Głoszenie i przekazywanie wiary jest nierozerwalnie związane ze świadectwem. Nadchodzi zatem czas, pisze Kasper, aby podjąć i uwydatnić na nowo związek pomiędzy teologią i świętością ${ }^{57}$. Wiarygodność głoszonego orędzia zależy bezsprzecznie od wiarygodności wspólnoty Kościoła ${ }^{58}$. Celem chrześcijańskiej katechezy w naszych czasach nie jest indoktrynacja, lecz indywidualnie zaakceptowana, przyjęta i niosąca odpowiedzi na współczesne wyzwania, odpowiedzialna i dojrzała wiara ${ }^{59}$. Taka zaś wiara daleka jest od nieruchomego trwania w okopach przeszłości, jest ona raczej drogą i dynamicznym procesem.

Wiara dojrzała staje się aktem całego człowieka, a zatem także jego umysłu. Tylko intelektualnie odpowiedzialna wiara jest godna Boga i człowieka, a w naszym „przenaukowionym” świecie o wysokim stopniu ogólnego wykształcenia całych społeczeństw, ma podwójne znaczenie ${ }^{60}$. Wiara chrześcijańska głoszona dzisiejszemu światu jako osobowa, całościowa i historyczno-konkretna odpowiedź człowieka na Boże wezwanie do nawrócenia i życia w wolności, wiara zawsze gotowa do obrony wobec każdego, kto domaga się uzasadnienia nadziei, która w nas jest (por. 1 P 3,15) ${ }^{61}$, musi odznaczać się rysem antropologicznym (odpowiedź na ludzkie pytania o sens), eschatologicznym (funkcja krytyczna dzięki wykazywaniu przemijalności wszystkich wartości świeckich) oraz charyzmatyczno-pneumatologicznym (wrażliwość na natchnienia Ducha Świętego) ${ }^{62}$. Tylko taka wiara jest w stanie głosić i skutecznie przekazywać każdej kolejnej epoce uniwersalne treści przejęte $\mathrm{z}$ objawienia.

\footnotetext{
${ }^{56}$ Por. W. Kasper, Tradierung und Vermittlung als systematisch-theologisches Problem, w: Tradierungskrise des Glaubens, red. E. Feifel, W. Kasper, München 1987 [odtąd skrót: Tradierung und Vermittlung], s. 49.

${ }^{57}$ Por. tenże, Tradierung und Vermittlung, s. 49-50.

${ }^{58}$ Por. tenże, Einführung, s. 63-64; tenże, Die Weitergabe des Glaubens, s. 27-34.

${ }^{59}$ Por. tenże, Tradierung und Vermittlung, s. 50; tenże, Die Zukunft des Glaubens, „Lebendige Seelsorge“ 1973, s. 16.

${ }^{60}$ Por. tenże, Tradierung und Vermittlung, s. 51; tenże, Hinführen zum Glauben - warum und wie?, „Internationale katholische Zeitschrift Communio“ 17(1988), nr 2, s. 97; tenże, Rechenschaft vom Glauben heute, „Universitas“ 28(1973), s. 1306.

${ }^{61}$ Por. tenże, Die Zukunft des Glaubens, „Lebendige Seelsorge“ 1973, s. 17; tenże, Hinführen zum Glauben - warum und wie?, „Internationale katholische Zeitschrift Communio“ 17(1988), nr 2, s. 98; tenże, Das Glaubensbekenntnis der Kirche, „Internationale katholische Zeitschrift Communio“ 13(1984), nr 3, s. 259, 270.

${ }^{62}$ Por. tenże, Die Zukunft des Glaubens, „Lebendige Seelsorge“ 1973, s. 17; tenże, Zukunft aus dem Glauben, Mainz 1978, s. 30-34.
} 
b) Katechizm dla dorosłych

Walter Kasper przewodniczył w przygotowaniu i wydaniu opublikowanego pod egidą Konferencji Episkopatu Niemiec „Katechizmu dla dorosłych” (Katholischer Erwachsenen-Katechismus, t. 1: Das Glaubensbekenntnis der Kirche, Kevelaer-München-Stuttgart-Limburg-Regensburg-Köln 1985). U podstaw zamysłu i realizacji tego dzieła znalazła się typowa dla tybingeńczyków i teologii Kaspera idea przekazu wiary, która jest głęboko związana z tradycją Kościoła, a jednocześnie otwarta na wyzwania współczesności.

We wierze chodzi o prawdę, która w swojej istocie może być tylko jedna, tak w ludzkim myśleniu i wszelkich procesach dyskursywnych, jak i w chrześcijańskim orędziu. Katecheza służy zatem także odpowiedzialności intelektualnej wiary. Katechizm katolicki musi się każdorazowo zmierzyć z wyzwaniami, jakie niesie ze sobą nowa epoka z jej myślą, wszechstronnym dorobkiem i kulturą ${ }^{63}$.

Współczesna forma przekazu wiary przez nowy „Katechizm dla dorosłych” jest jednak nierozdzielnie związana z wypracowanym przez wieki w Kościele dziedzictwem tradycji i duchem misyjnym, zaznacza Kasper ${ }^{64}$. Tradycja nie jest bowiem rodzajem bezrefleksyjnego przekazywania prawd wiary (,zdań katechizmowych"), tak jak przekazuje się z rąk do rąk martwą i zimną monetę. Jest ona raczej czymś z natury ogromnie witalnym - wypływając z żywej wiary, do żywej wiary pragnie prowadzić 65 .

c) Istota i posłannictwo urzędu kapłańskiego

Wszystkie, nawet najbardziej szczytne i interesujące idee, pozostaną na papierze, jeśli nie zostaną wcielone w życie na ,pierwszym froncie” przez kapłanów i ich współpracowników w pastoralnej praktyce Kościoła. Stąd właśnie w zagadnieniu właściwego rozumienia urzędu i posługi kapłańskiej (Problematik des Priesteramtes) ogniskują się i wyszczególniają wszystkie wyzwania, z jakimi Kościół miał do czynienia na polu przekazu wiary na przestrzeni ostatnich kilkudziesięciu lat ${ }^{66}$.

${ }^{63}$ Tenże, Das Glaubensbekenntnis der Kirche, ,Internationale katholische Zeitschrift Communio“13(1984), nr 3, s. 258.

${ }^{64}$ Por. tenże, Hinführen zum Glauben - warum und wie?, „Internationale katholische Zeitschrift Communio“ 17(1988), nr 2, s. 99-103.

${ }^{65}$ Por. tenże, Die Weitergabe des Glaubens, s. 22.

${ }^{66}$ Por. tenże, Sein und Sendung des Priesters, „Geist und Leben“ 51(1978), nr 3, s. 196. Dla uzyskania szerszej panoramy przytoczmy choćby niektóre tylko publikacje Waltera Kaspera na temat urzędu i posługi kapłańskiej w Kościele: Neue Akzente im dogmatischen Verständnis des priesterlichen Dienstes, „Concilium“ (D) 5(1969), s. 164-170; Die Funktion des Priesters in der Kirche, „Geist und Leben“ 42(1969), nr 2, s. 102-116; Krise und Wagnis des Glaubens im Leben des Priesters, „Geist und Leben“ 42(1969), nr 4, s. 244-250; Amt und Gemeinde, w: tenże, Glaube und Geschichte, Mainz 1970, s. 388-414; Das priesterliche Dienstamt, „Diakonia - Der Seelsorger“ 
Wierność tradycji Kościoła, niezbędna w sprawowaniu posługi kapłańskiej we wspólnocie wierzących ${ }^{67}$, jest u Kaspera integralnie związana $\mathrm{z}$ jego postulatem konieczności otwarcia na problematykę współczesności. Osoba Jezusa Chrystusa, który jest kluczem, centrum i celem całej ludzkiej historii, rzuca snop jasnego światła na wszystkie obszary naszej rzeczywistości, także na naukę i kulturę, gospodarkę i politykę ${ }^{68}$. Nie możemy, jak uczy nas Biblia, ograniczać działania Bożego Ducha, tylko do granic wspólnoty Kościoła. On sięga dalej i szerzej, wieje, kędy chce. Jest obecny w całym stworzeniu, przenikając i obejmując dzieje rasy ludzkiej i świata. Prowadzi całą historię ludzkości ku nadchodzącemu królestwu wolności dzieci Bożych, pisze Kasper ${ }^{69}$.

Stąd właśnie człowiek duchowy powinien się wystrzegać ograniczenia swojego horyzontu myślowego do poczucia bezpieczeństwa i komfortu swoich czterech ścian. Musi on uważnie odczytywać znaki czasu i wsłuchiwać się w „,proroctwo" świata, aby uwzględniając pytania współczesności, lepiej i głębiej rozumieć samą Ewangelię oraz przepajać jej duchem konkretne przejawy naszej rzeczywistości. Posłannictwo kapłana staje się w takiej perspektywie nie tylko służbą w Kościele, ale także z Kościołem i poprzez niego wobec całego świata ${ }^{70}$. „Gdyż oderwanie zbawienia od rzeczywistości świata [weltloses Heil] doprowadziłoby z konieczności do oderwania świata od nadziei zbawienia [heillose Welt]. Wynika z tego, że kapłani muszą być ludźmi, którzy dysponując odpowiednimi kwalifikacjami serca i umysłu, nie zawahają się podjąć dialogu ze współczesnością" ${ }^{1}$. Księża naszych czasów muszą być nieustannie gotowi do obrony wobec każdego, kto domaga się uzasadnienia nadziei, która w nas jest (por. 1 P 3,15) ${ }^{72}$.

4(1971), s. 222-232; Priesterbildung und Priesterausbildung heute. Theologische Überlegungen zu den neusten Umfrageergebnissen, „Theologische Quartalschrift“ 155(1975), s. 300-318; Die schädlichen Nebenwirkungen des Priestermangels, ,Stimmen der Zeit“ 195(1977), nr 2, s. 129-135; Sein und Sendung des Priesters, „Geist und Leben“ 51(1978), nr 3, s. 196-212; Das kirchliche Amt in der Diskussion. Zur Auseinandersetzung mit E. Schillebeecks, „Das kirchliche Amt“, „Theologische Quartalschrift“ 163(1983), nr 1, s. 46-51; Kirchenamt, w: Staatslexikon. Recht - Wirtschaft Gesellschaft, hrsg. v. der Görres-Gesellschaft, t. 3 (1987), s. 413-416; Gemeindeaufbau und Gemeindeleitung: Zentrale Perspektiven angesichts des Priestermangels, hrsg. vom Bischöflichen Ordinariat der Diözese Rottenburg-Stuttgart, Rottenburg 1991, s. 3-19.

${ }^{67}$ Kasper wspomina o tym z naciskiem w swoich publikacjach: Neue Akzente im Verständnis des priesterlichen Dienstes, „Concilium“ (D) 5(1969), s. 164-170; Die Funktion des Priesters in der Kirche, w: tenże, Glaube und Geschichte, Mainz 1970, s. 371-387; Die Heilssendung der Kirche in der Gegenwart, Mainz 1970, s. 69-89; Sein und Sendung des Priesters, „Geist und Leben“ 51(1978), nr 3, s. 196-212; Das kirchliche Amt in der Diskussion. Zur Auseinandersetzung mit E. Schillebeecks, „Das kirchliche Amt“, „Theologische Quartalschrift“ 163(1983), s. 46-51.

${ }^{68}$ Por. tenże, Diener eurer Freude, „Berufung. Zur Pastoral der geistlichen Berufe“, z. 36, Freiburg 1998, s. 7.

${ }^{69}$ Por. tenże, Sein und Sendung des Priesters, „Geist und Leben“ 51(1978), nr 3, s. 209-210.

${ }^{70}$ Por. tamże, s. 210.

${ }^{71}$ W. Kasper, Diener eurer Freude, „Berufung. Zur Pastoral der geistlichen Berufe“, z. 36, Freiburg 1998, s. 7.

${ }^{72}$ Por. tamże. 
d) Dialog Kościoła ze światem

W minionych wiekach Kościół wielokrotnie podkreślał znaczenie oraz bronił zasad tradycji i autorytetu z nią związanego, gdyż nieustannie musiał się opierać atakom z zewnątrz. Oczywiście, w przypadku każdej strategii defensywnej, naczelną zasadą jest utrzymywanie dyscypliny. Jakiekolwiek dyskusje wewnętrzne osłabiają strategię obronna, a dialog $\mathrm{z}$ otoczeniem łatwo może zostać zinterpretowany jako zdrada ideałów. Tak więc dewizą Kościoła stała się zwartość szeregów w aspekcie wewnętrznym i zewnętrznym ${ }^{73}$.

Niemniej jednak dialog ze światem (Dialog der Kirche mit der Welt) jest dla Kościoła czymś niezbędnym, chociażby dlatego, pisze Kasper, że Kościół na wzór Chrystusa ma opierać swoje posłannictwo na służbie ${ }^{74}$. To nie ludzie są dla Kościoła, ale Kościół dla ludzi. Możemy zatem mówić o poważnej odpowiedzialności Kościoła nie tylko przed Bogiem i trybunałem sądu ostatecznego, lecz także przed osądem świata i historii ${ }^{75}$.

Podtrzymaniu ubogacającego obie strony płodnego dialogu nie służy postrzeganie Kościoła i świata w kategoriach przedsoborowego modelu, odwołującego się do integryzmu ${ }^{76}$. Jego zwolennicy pragnęli wyprowadzić $\mathrm{z}$ teologicznych założeń konkretne rozwiązania dotyczące rzeczywistości świeckiej (pokusa klerykalizmu), nie biorąc pod uwagę zalecanego w następnych latach przez Sobór Watykański II uznania autonomii spraw ziemskich ${ }^{77}$.

Równie niezdatny okazuje się zresztą drugi model, nazywany przez Kaspera funkcjonalnym, w którym Kościół zostaje odsunięty poza teren głównego nurtu życia i kultury do obszaru, gdzie wymaga się od niego jedynie funkcji uatrakcyjniania określonych wydarzeń społecznych i niesienia taniej pociechy wobec empirycznie rozpoznawalnej przygodności naszego istnienia lub - w bardziej radykalnej wersji - funkcji lokomotywy w procesach przekształcających stosunki społeczne $^{78}$.

Tylko trzeci (zaproponowany przez ojców soborowych, a przez kardynała Kaspera podjęty) model, który nazywany jest drogą chrześcijańskiej odpowiedzialności za świat, może podołać zadaniu przepojenia od wewnątrz naszej rzeczywistości światłem i mocą Ewangelii, co zresztą zawsze było zgodnie uznawane za najważniejsze zadanie Kościoła ${ }^{79}$.

Całe obszary świeckiej kultury, gospodarki czy polityki mają własne, uznawane przez Kościół prawa i zasady funkcjonowania. Pociąga to za sobą określo-

${ }^{73}$ Por. tenże, Kirche nach dem Konzil, w: Christliche Verantwortung, red. V. Hochgrebe, Würzburg 1968 [odtąd skrót: Kirche nach dem Konzil], s. 306.

${ }^{74}$ Por. tamże, s. 308

${ }^{75}$ Por. tamże, s. 307-308.

${ }^{76}$ Por. tenże, Zur Situation, s. 19.

${ }^{77}$ Por. tamże.

${ }^{78}$ Por. tamże.

${ }^{79}$ Por. tamże. 
ne trudności z adekwatnym wskazaniem, co mówi nam wiara $\mathrm{w}$ odniesieniu do konkretnych przypadków, bez uwzględnienia czasu i pojęciowego horyzontu epoki $^{80}$. Stąd nie możemy ograniczać się wyłącznie do lektury Pisma Świętego czy dokumentów Magisterium. Nasz cel możemy osiagnąć jedynie przez odniesienie całej rzeczywistości do Jezusa Chrystusa, w którym teologia musi umieć postrzegać absolutną jedność natury i łaski, stworzenia i odkupienia oraz ostateczne odniesienie ludzkiej wolności, jedności i zbawienia człowieka i świata ${ }^{81}$.

Otwartość Waltera Kaspera na zagadnienia współczesności manifestuje się także w jego wypowiedziach i publikacjach na temat roli teologii i Kościoła we współczesnej, jednoczącej się Europie (Rolle der Kirche und der Theologie in Europa). Z uwagi na brak miejsca odeślemy tylko do niektórych jego tekstów na ten temat ${ }^{82}$.

\subsubsection{Dialogiczna otwartość teologii na współczesny świat}

Teologia jako racjonalna refleksja nad treściami wiary służy Kościołowi, a ten z kolei jest posłany, aby głosić Ewangelię wszelkiemu stworzeniu. Kasper pisze w nawiązaniu do dorobku i postaci Karla Adama, jednego z teologów tybingeńskich: „To właśnie jest prawdziwy katolicyzm: afirmacja najlepszych ludzkich wartości i otwartość na świat w najszerszym i najszlachetniejszym rozumieniu tego słowa"83.

Ta otwartość refleksji teologicznej na świat przejawia się u Kaspera przede wszystkim w filozoficznych dywagacjach dotyczących prawdy, wolności oraz udziału w debacie dotyczącej zjawiska współczesnej sekularyzacji.

a) Otwartość w procesie filozoficznego poszukiwania prawdy

Walter Kasper jest zdania, że chrześcijanin jest człowiekiem, który ze względu na swoją wiarę i dzięki zakorzenieniu w Absolucie, objawionym nam w Chrystusie i przez Chrystusa, nieuchronnie skłaniać się powinien ku zagadnieniom filozoficznym ${ }^{84}$. Taka postawa jest konieczna, gdyż historyczna postać biblijnej

\footnotetext{
${ }^{80}$ Por. W. Kasper, Kirche nach dem Konzil, s. 315; tenże, Natur-Gnade-Kultur, „Theologische Quartalschrift“ 170(1990), nr 2 [odtąd skrót: Natur-Gnade-Kultur], s. 92; Zur Situation, s. 19.

${ }^{81}$ Por. tenże, Natur-Gnade-Kultur, s. 81-97; tenże, Kirche und neuzeitliche Freiheitsprozesse, w: Vernunft des Glaubens. Festschrift zum 60. Geburtstag von Wolfhart Pannenberg, red. J. Rohls, G. Wenz, Göttingen 1988, [odtąd skrót: Kirche und Freiheitsprozesse], s. 593-610.

${ }^{82}$ W. Kasper, Einheit Europas in Wahrheit und Freiheit, w: ET, Bulletin 3(1992), s. 95-100; Neuevangelisierung in Europa: Eine Anfrage an christliche Führungskräfte, „Land aktuell“ 44(1992), s. 199-202; Europäisches Denken und christliche Botschaft, w: Aufklärung durch Tradition, red. H. Fechtrup, F. Schulze, T. Sternberg, Münster 1995, s. 109-122; Ser cristiano en la Europa de los años 90, w: Cristianismo y cultura en la Europa de los años 90, red. W. Kasper, G. Amengual, J. Daniel i in., Madrid 1993, s. 9-27.

${ }^{83}$ Tenże, Karl Adam, s. 254.

${ }^{84}$ Por. tenże, Bóg Jezusa Chrystusa, s. 24.
} 
prawdy wymaga od nas umieszczenia jej w ramach racjonalnej spekulacji, która z kolei zakłada dzieje ludzkości i świata jako ostateczny horyzont całej rzeczywistości ${ }^{85}$.

Ten typ spekulacji filozoficznej stwarza dla teologii niedostępne dotąd możliwości i szanse, które lepiej odpowiadają specyficznemu, teologiczno-biblijnemu pojmowaniu prawdy i realiów świata niż dotychczasowe formy myślenia w kategoriach statyczno-naturalnych ${ }^{86}$. Oczywiście, także typ myślenia statycznego minionej epoki, opartego na odniesieniu do stałego porządku i struktury bytu, jest i był myśleniem na wskroś filozoficznym. Kasper podkreśla jednakże w swoich publikacjach rangę zdobyczy nowszych kierunków filozoficznych, uwzględniających w swojej refleksji czynnik zmiany i historii. Czyni to dlatego, że lepiej odpowiadają mentalności człowieka współczesnego, jego refleksji nad samym sobą i światem, w którym żyje ${ }^{87}$, co z kolei sprawia, że lepiej się nadają, aby transponować odwieczną prawdę Ewangelii w przemijającą i przekształcającą się w olbrzymim tempie ludzką codzienność.

W tym kontekście bardzo pomocne okazało się dla Kaspera studium dorobku myślowego Schellinga i jego próby przezwyciężenia rozdziału pomiędzy filozofią praktyczną i teoretyczną, podmiotem i przedmiotem, pomiędzy prawdą i bytem ${ }^{88}$. Schelling, usiłując przerzucić kładkę pomiędzy filozofią teoretyczną a praktyczną (rozdział dokonany przez I. Kanta, zrywający więź bytu i myśli), pojmuje Absolut jako podstawowe odniesienie i horyzont intelektualnej refleksji człowieka, przy czym zasadniczym działaniem ducha ludzkiego jest wolny $\mathrm{w}$ swej istocie $\mathrm{akt}^{89}$. Zarazem stwierdza, że prawdziwego poznania owego Absolutu nie osiaga się na drodze wysiłków myślowych, lecz jedynie, gdy sam się nam objawia poprzez swe działanie, które ma miejsce jako wyraz i realizacja wolności absolutnej ${ }^{90}$. Człowiek doświadcza owego działania właśnie w ramach dziejów. W procesie dziejowym dochodzi do spotkania poszukującego prawdy, sensu i celu człowieka z objawiającym się Bogiem. Musi on przy tym zrozumieć, że nie ma innej drogi do osiągnięcia obcowania z prawdą Absolutu, jak tylko po-

${ }^{85}$ Por. tenże, Die Methoden, s. 73.

86 Por. tamże.

${ }^{87}$ Por. tenże, Kirche und Theologie unter dem Gesetz der Geschichte, w: tenże, Glaube und Geschichte, Mainz 1970, s. 49-66; Grundlinien einer Theologie der Geschichte, w: tenże, Glaube und Geschichte, Mainz 1970, s. 67-100 i na wielu innych miejscach.

${ }^{88}$ Por. tenże, Neuere philosophische Denkformen in der Theologie, ,Münchener Theologische Zeitschrift" 29(1978), s. 426-431; Das Absolute, s. 438; W.P. Loewe, The New Catholic Tübingen Theology of Walter Kasper: Foundational Issues, „Heythrop Journal” 21(1980), s. 32-35; N. Madonia, Ermeneutica e cristologia in Walter Kasper, Palermo 1990, s. 44-46; A. Nichols, Walter Kasper and His Theological Programme, „New Blackfriars” 1(1986), s. 19-20.

${ }^{89}$ Por. N. Podhorecki, Jezus Chrystus jako concretum universale w myśli teologicznej Waltera Kaspera, w: Jezus Chrystus w refleksji wspótczesnych teologów, red. B. Kochaniewicz, Colloquia Disputationes 21, Poznań 2013, s. 79.

${ }^{90}$ Por. W. Kasper, Das Absolute, s. 425. 
zwolić się obdarować łaską bliskości przez Niego samego, który czyni to z kolei w akcie swojej absolutnej wolności ${ }^{91}$.

Wiara chrześcijańska uczy, że Bóg objawia się człowiekowi najpełniej w historycznym wydarzeniu osoby i dzieła Jezusa Chrystusa, który zajmuje dzięki temu szczególne miejsce $\mathrm{w}$ dialogu wolności pomiędzy Bogiem a człowiekiem. To Chrystus staje się pośrednikiem prawdy i wieczności Absolutu w całej zmienności dziejów człowieka i świata ${ }^{92}$. Dlatego właśnie Walter Kasper wskazuje na Zbawiciela jako na concretum universale. W Jezusie Chrystusie, w konkretnym człowieku, żyjącym wśród nas w określonych i niepowtarzalnych warunkach czasu i przestrzeni, kultury i społeczności, języka i tradycji, objawia się w absolutny i nieprzewyższalny sposób to, co prawdziwe, całościowe, konieczne i boskie. To, co w poszczególnych epizodach dziejów ukazuje się na sposób fragmentaryczny, na sposób antycypacji, w wydarzeniu Jezusa Chrystusa zrealizowane jest na sposób absolutnie uniwersalny. Zrealizowane nie tyle metafizycznie i pojęciowo, ile raczej na sposób osobowego, a zarazem historycznego wydarzenia - spotkania z osobowym, samoudzielającym się i pełnym życzliwości i miłości dla swojego stworzenia Bogiem ${ }^{93}$.

Jezus Chrystus, jako punkt kulminacyjny samoobjawienia się Boga, staje się pośrednikiem niezmienności, uniwersalności i prawdy Absolutu w zmienności i przygodności dziejów (das Absolute in der Geschichte) właśnie dzięki temu, że w misterium Chrystusa Bóg bierze udział w historii oraz kruchości naszej egzystencji wraz z jej przemijaniem, a świat i dzieje stanowią miejsce objawienia Ewangeliii ${ }^{94}$.

b) Zagadnienie wolności

Jeśli chciałoby się adekwatnie ująć dziejową zmianę paradygmatu, która dokonała się w przejściu od czasów starożytności i średniowiecza w epokę nowożytną, to bez wątpienia można zaryzykować stwierdzenie, że byłoby to wielopłaszczyznowo ujęte zagadnienie wolności.

Wolność w filozofii nowożytnej nie wywodzi się już z porządku bytowego, to raczej wszelki porządek w sferze ontologicznej musi się odnosić do wolności, a także poprzez wolność i w odniesieniu do niej powstaje. Dzisiaj cały porządek naszej rzeczy-

${ }^{91}$ Por. W. Kasper, Die Freiheit als philosophisches und theologisches Problem in der Philosophie Schellings, w: W. Kasper, Glaube und Geschichte, Mainz 1970, s. 42.

${ }^{92}$ Por. N. Podhorecki, Jezus Chrystus jako concretum universale w myśli teologicznej Waltera Kaspera, w: Jezus Chrystus w refleksji wspótczesnych teologów, red. B. Kochaniewicz, Colloquia Disputationes 21, Poznań 2013, s. 80.

${ }_{93}$ Por. tamże, s. 92.

${ }^{94}$ Por. tamże, s. 93; W. Kasper, Die Welt als Ort des Evangeliums, w: tenże, Glaube und Geschichte, Mainz 1970 [odtąd skrót: Die Welt], s. 209-223. 
wistości istnieje dzięki wolności i dla wolności. W miejsce metafizycznego ładu istoty rzeczy pojawia się międzypodmiotowy ład wolności ${ }^{95}$.

Walter Kasper pisze, że wielka rola i zarazem kryzys wolności należą do najpoważniejszych „znaków czasu” naszej epoki. Ku nim musi się zwrócić teologia, chcąc mówić o Bogu w odpowiedzialny, bo przystosowany do możliwości współczesnego człowieka sposób ${ }^{96}$.

Dzisiejsze czasy i człowiek współczesny domagają się wolności na różnych płaszczyznach: od nacisków politycznych, od ubezwłasnowolnienia przez różnego rodzaju organizacje (także ze strony Kościoła), od religijnych przesądów, od społecznej niesprawiedliwości. Głośno mówi się o wolności obywatelskiej, wolności wyznania, słowa, prasy, zgromadzeń, sumienia, w końcu o wolności chrześcijańskiej ${ }^{97}$.

Niewatpliwie jedną z przyczyn owego powszechnego wołania o wolność w społeczeństwie i w filozofii nowożytnej był przełom, jaki dokonał się w ostatnich wiekach na kontynencie europejskim. Idea osoby jako podmiotu świadomego, określającego siebie, słowem wolność ludzka, rozumiana jako autonomiczna, stała się sercem i ośrodkiem świadomości współczesnego człowieka ${ }^{98}$. Dokonało się przejście z powszechnie uznawanego w starożytności i średniowieczu porządku teonomicznego (rozumienia całości rzeczywistości jako opartej na Bogu i Jego prawie) ku emancypacji i autonomiczności wszystkich poszczególnych płaszczyzn życia społecznego i indywidualnego - nauki, kultury, gospodarki, sztuki, polityki i in. Ów nowożytny sposób myślenia, począwszy od Kartezjusza, doprowadził do skoncentrowania uwagi na samym człowieku. Po załamaniu się dotychczasowego porządku i upowszechnieniu świadomości niestałości rzeczywistości to właśnie człowiek stał się dla nowożytnej filozofii niewzruszonym fundamentem, punktem wyjścia i odniesienia, rozumienia świata i wartości ${ }^{99}$. Immanuel Kant poprowadził ten sposób myślenia konsekwentnie dalej. Dla niego na wolności i autonomii ludzkiej woli zasadza się w zasadniczy sposób godność człowieka ${ }^{100}$.

Zasadniczy zwrot $\mathrm{w}$ dotychczasowym rozumieniu kategorii wolności na płaszczyźnie filozoficznej szedł w parze z przemianami życia społecznego i go-

${ }^{95}$ Tenże, Christliche Freiheit und neuzeitliche Autonomie, w: Menschenwürdige Gesellschaft, hrsg. v. d. Salzburger Hochschulwochen, Graz 1977 [odtąd skrót: Christliche Freiheit], s. 77.

${ }^{96}$ Por. tamże, s. 73.

${ }^{97}$ Por. tamże, s. 74.

${ }^{98}$ Por. Th. Pröpper, Freiheit, w: Neues Handbuch theologischer Grundbegriffe t. 1, red. P. Eicher, München 1984, s. 387-403; Kongregacja Nauki Wiary, Instrukcja o chrześcijańskiej wolności i wyzwoleniu (22.03.1986), 5-19.

${ }^{99}$ Por. W. Kasper, Christliche Freiheit, s. 76.

${ }^{100}$ Por. tenże, Autonomie und Theonomie. Zur Ortsbestimmung des Christentums in der modernen Welt, „Theologisches Jahrbuch“ 1982 [odtąd skrót: Autonomie und Theonomie], s. 180-181. 
spodarczego. Upadek społecznych struktur politycznych i religijnych pod koniec średniowiecza oderwał wolność ludzką od natury i tradycji religijnej. Wolność straciła swój dotychczasowy związek z szerokim kontekstem metafizycznym i teologicznym. Zaczęła być pojmowana jako autonomiczna, samodzielnie ustalająca swoje prawa. Stała się czymś bezwarunkowym i definitywnym, testującym i regulującym każdą inną wartość. Kasper nazywa to głęboką wewnętrzną ambiwalencją współczesnej koncepcji wolności ${ }^{101}$. Samorealizacja i pragnienie samooczyszczenia bez pierwiastka religijnego i bez Boga wyczerpywała się w kolejnych rozpaczliwych wysiłkach ludzi i społeczeństw. Droga opierania się tylko na sobie doprowadziła człowieka i współczesną Europę na skraj przepaści. $\mathrm{Z}$ tego też powodu nowożytnej idei wolności towarzyszy głęboki niepokój. Kasper thumaczy go pomyleniem bezwarunkowości wolności z jej absolutem ${ }^{102}$.

Tymczasem teologiczna nauka o absolutnej wolności Boga jest zarazem wołaniem o wolność i godność ludzką oraz ugruntowaniem i ochroną transcendencji osoby ludzkiej. Według Kaspera, Ratzingera i innych myślicieli chrześcijańskich, w ramach teologii wolności należy krytycznie i twórczo przepracować charakterystyczny dla nowożytnej filozofii program wolności poprzez zwrócenie uwagi na istotny, wewnętrzny związek pomiędzy wolnością, prawda, prawem i miłością ${ }^{103}$. Krótko mówiąc, teologia musi pomóc nowożytnej filozofii krytycznie ustosunkować się do wolności i wyzwolić od jej niewłaściwego rozumienia.

Walter Kasper pisze, że możliwe jest krytyczne przejęcie i pozytywne wykorzystanie dla orędzia Ewangelii dorobku współczesnych prądów filozoficznych, odwołujących się do dziedzictwa fenomenologii i egzystencjalizmu oraz akcentujących wymiar wolności człowieka jako podstawę jego egzystencji. Dostrzega on taką możliwość w syntezie modelu autonomii i teonomii św. Tomasza z Akwinu z osiagnięciami współczesnej filozofii oraz jej dowartościowaniem wolności ${ }^{104}$. Akwinata mocno akcentował, że łaska zakłada naturę i ją udoskonala ${ }^{105}$. W odniesieniu do nowożytnej problematyki wolnościowej owa maksyma otrzymałaby według Kaspera nowe brzmienie: Teonomia zakłada ludzką autonomię, ponieważ uznanie Boga w Jego absolutnym bycie może dokonać się jedynie

${ }^{101}$ Por. W. Kasper, Kościót $i$ wolność, tłum. J. Skupieńska, „Chrześcijanin w Świecie” 25(1995), nr 2 [odtąd skrót: Kościót $i$ wolność], s. 28; oryg. franc.: L'Église et les processus modernes de la liberté, „La Documentation Catholique“ 77(1995), s. 238-245.

${ }^{102}$ Por. tamże.

${ }^{103}$ Por. tenże, Wahrheit und Freiheit: Die „Erklärung über die Religionsfreiheit“ des zweiten Vatikanischen Konzils, Heidelberg 1988 [odtąd skrót: Wahrheit und Freiheit], s. 40; tenże, Kościót $i$ wolność, s. 25-41; J. Ratzinger, Wiara - prawda - tolerancja. Chrześcijaństwo a religie świata, Kielce 2004; J. Ratzinger, Prawda w teologii, Kraków 2005 i in.

${ }^{104}$ Por. N. Podhorecki, Filozofia i teologia w interdyscyplinarnym dialogu, ,Studia Sandomierskie" 12(2005), z. 2, s. 140-142.

${ }^{105}$ Por. Tomasz z Akwinu, Summa Theologiae, I, 1, 8 ad 2: „cum enim gratia non tollat naturam sed perficiat". 
poprzez wolny i odpowiedzialny akt wolitywno-poznawczy człowieka. Odpowiednio także ludzka wolność i autonomia osiaga pełnię swego istnienia i spełnienie poprzez teonomię, poprzez uznanie Boga za Pana i poprzez wspólnotę z Nim ${ }^{106}$. W świetle nowożytnego akcentowania podmiotowości człowieka, pojmowania rzeczywistości i rozumowania w kategoriach wolności można sformułować następującą tezę: „Łaska i prawda zakładają wolność i udoskonalają ją”107. Teologia ma właśnie za zadanie ukazać spragnionemu wolności współczesnemu człowiekowi, że prawdziwa wolność i wezwanie do niej w najbardziej konkretnym i historycznym kształcie ukazały się w osobie Jezusa Chrystusa ${ }^{108}$.

c) Teologia i wiara wobec pluralistycznego, zsekularyzowanego świata

Praktycznie zorientowana otwartość teologii Kaspera, która wyraża się w dialogu ze współczesnością poprzez wspólne poszukiwania rozumienia prawdy i wolności, prowadzi go do zajęcia się jednym z najważniejszych wyzwań stojących przed Kościołem naszych czasów, jego misja w świecie i zabiegami o przekazywanie wiary następnym pokoleniom - chodzi o przybierający na sile proces sekularyzacji jednostek i całych społeczeństw ${ }^{109}$.

106 Por. W. Kasper, Autonomie und Theonomie, s. 189.

${ }^{107}$ Tamże, s. 190.

${ }^{108}$ Por. tenże, Jesus der Christus, Mainz 1992.11, Vorwort zur elften Auflage, XXI.

${ }^{109}$ Podamy tu kilka miejsc i odnośnych publikacji Kaspera na ten temat: Grundlinien einer Theologie der Geschichte, w: tenże, Glaube und Geschichte, Mainz 1970, s. 80; Gott in der Geschichte, w: Gott heute. 15 Beiträge zur Gottesfrage, red. N. Kutschki, Mainz-München 1967, s. 142, 148; Die Verwirklichung der Kirche in Ehe und Familie. Überlegungen zur Sakramentalität der Ehe, w: tenże, Glaube und Geschichte, Mainz 1970, s. 333; Neue Akzente im dogmatischen Verständnis des priesterlichen Dienstes, „Concilium“ (D) 5(1969), s. 164-165; Die Theologie angesichts des heutigen Atheismus, w: Gott-Frage und moderner Atheismus, red. J. Blank i in., Regensburg 1969, s. 73-104; Die Verkündigung als Provokation, w: tenże, Glaube und Geschichte, Mainz 1970, s. 227-230; Einführung in den Glauben, Mainz 1972, s. 14-18; Gottes Glaube im Angesicht von säkularisierter und atheistischer Umwelt, w: Ein Gott für die Welt. Glaube und Sinnfrage in unserer Zeit, red. H. Wieh, München 1980, s. 37-55; Bóg Jezusa Chrystusa, Wrocław 1996, s. 14-21, 26-90; Die Weitergabe des Glaubens. Schwierigkeit und Notwendigkeit einer zeitgemäßen Glaubensvermittlung, w: Einführung in den katholischen Erwachsenenkatechismus, red. tenże, Schriften der Katholischen Akademie in Bayern 118, Düsseldorf 1985, s. 13-21; Tradierung und Vermittlung als systematisch-theologisches Problem, w: Tradierungskrise des Glaubens, red. E. Feifel, W. Kasper, München 1987, s. 30-35; Säkularisierung, w: Staatslexikon. Recht - Wirtschaft - Gesellschaft, hrsg. v. der Görres-Gesellschaft, t. 4(1988), s. 993-998; Kirche und neuzeitliche Freiheitsprozesse. Festvortrag bei der Generalversammlung der Görresgesellschaft vom 3.-7. Oktober 1987 in Augsburg, w: Vernunft des Glaubens, red. J. Rohls, G. Wenz, Göttingen 1988, s. 593-610; Natur-Gnade-Kultur. Zur Bedeutung der modernen Säkularisierung, „Theologische Quartalschrift" 170(1990), nr 2, s. 81-97; Evangelisierung und Neuevangelisierung. Überlegungen zu einer neuen pastoralen Perspektive, w: Verantwortung für den Glauben: Beiträge zur Fundamentaltheologie und Ökumenik. Festschrift für H. Fries, red. P. Neuner, H. Wagner, Freiburg im Breisgau 1992, s. 236-238; Die Kirche angesichts der Herausforderungen der Postmoderne, „Stimmen der Zeit" 215(1997), s. 651-664. 
Pod pojęciem „sekularyzacja” Kasper rozumie proces w obrębie kultury i życia społecznego, który doprowadził do wyeliminowania zasadniczych odniesień do nadprzyrodzoności i transcendencji w pojmowaniu świata oraz wszelkiej aktywności na jego obszarach składowych (polityce, kulturze, gospodarce, nauce) i do takiego obchodzenia się z nimi, jakby świat był całkowicie immanentny ${ }^{110}$. Sekularyzm traktuje całą rzeczywistość przez pryzmat naturalnych odniesien, bazując na naturalizmie i materializmie.

Emancypacja od przekazywanych przez wieki tradycji tematów tabu (wolność), rozpad autorytarnych konwencji w życiu społecznym i triumf demokracji (równość), w końcu uczynienie bardziej ludzkimi wielu elementów i obszarów życia i zdecydowana poprawa jego ogólnej jakości (braterstwo) - oto słowa klucze dzisiejszego świata i społeczeństwa ${ }^{111}$. Oczywiście, wszystkie one nawiązują w jakiś sposób do orędzia głoszonego przez wieki w Kościele, będąc także wyrazem chrześcijańskiego posłannictwa,

tym niemniej sposób, w jaki są one dzisiaj praktycznie pojmowane i realizowane, redukuje wiarę i usuwa ją na margines życia. Ciaggle bowiem podejmuje się próby realizacji tych szczytnych celów i idei z całkowitym pominięciem Kościołów chrześcijańskich. Prowadzi to do powstania sytuacji, w której wiara nieustannie traci swoją społeczną wiarygodność i znaczenie ${ }^{112}$.

Istota wiary i tradycji Kościoła, która odnosi się przede wszystkim do orędzia o Krzyżu i zmartwychwstaniu Chrystusa, będącym ucieleśnieniem Bożej miłości do człowieka i stworzenia, przekazywana jest niejednokrotnie za pomocą terminów i pojęć obcych współczesnemu człowiekowi. Zasadnicze pojęcia chrześcijańskiej wiary, jak: Bóg, objawienie, łaska, grzech, zbawienie, na naszych oczach tracą zakorzenienie w doświadczeniu życiowym i horyzoncie myślowym współczesnego obywatela świata Zachodu. Kościołowi, wraz z jego uniwersalnym przesłaniem wiary, w wypadku pogłębiania się tego procesu grozi niebezpieczeństwo przeobrażenia się w oczach społeczeństwa w swojego rodzaju sektę ${ }^{113}$.

Stąd pytania w rodzaju: Wierzyć - cóż to właściwie oznacza? W jaki sposób mówić przekonująco o wierze we współczesnym, zsekularyzowanym świecie? Po co w ogóle wierzyć, wyznawać publicznie wiarę i przekazywać ją następnym pokoleniom? ${ }^{114}$ - stają się aktualnym zadaniem praktycznie zorientowanej teologii.

\footnotetext{
${ }^{110}$ Por. W. Kasper, Bóg Jezusa Chrystusa, s. 15.

${ }^{111}$ Por. tenże, Die Zukunft des Glaubens. Thesen zur Krise der westdeutschen Synode, „Lebendige Seelsorge“" 1973, s. 16.

112 Tamże.

${ }^{113}$ Tenże, Die Funktion der Theologie in der Kirche, w: Die Zukunft der Theologie in der Kirche. Berichtband des Concilium-Kongresses 1970, Zürich 1971, s. 45.

${ }^{114}$ Por. tenże, Was alles Erkennen übersteigt, Freiburg 1987, s. 14-15.
} 
1. „Według Soboru Watykańskiego II ateizm należy do «najpoważniejszych spraw obecnej doby», należy do "znaków czasu»" 115 - pisze Walter Kasper. Fenomen ateizmu mas, występujący po raz pierwszy w historii ludzkości na tak szeroką skalę, jest oczywiście powiązany z omawianym przez nas zjawiskiem sekularyzacji. Sam ateizm Kasper charakteryzuje jako pogląd zaprzeczający istnieniu jakiejkolwiek formy absolutu czy bóstwa, która nie byłaby identyczna z człowiekiem i ze światem naszego empirycznego doświadczenia i jego wewnętrznych pryncypiów ${ }^{116}$.

Początki tego typu myślenia mają zresztą swoje oparcie w spekulacjach teologicznych. Emancypacja autonomii człowieka z jej kontekstu o wymiarze teonomicznym, a tym samym stworzenie przesłanek dla powstania nowożytnego ateizmu pojawiły się, według Kaspera, wraz z późnoscholastycznym nominalizmem. „Nominalizm wzmógł myśl o wszechmocy i wolności Boga do ekstremalnego stanu absolutystycznej samowoli Boga. Rewolta przeciwko takiemu, niedopuszczającemu wolności człowieka, lecz uciskającemu Bogu, który mógł także nakazać nieprawdę i niesprawiedliwość, była aktem samopotwierdzenia się człowieka" 117 . Wyjście od ego cogitans Kartezjusza, od siebie jako podmiotu, pojmującego siebie jako podmiot, stała się w konsekwencji punktem archimedesowym na całą nowożytność. Odtąd podmiotowość jest nowożytną formą myślenia i podstawą wszelkiej myślii118.

Chociaż Kasper często mówi o ateizmie własnego (czyli nas, wierzących) serca $^{119}$, to podaje on także jego zasadniczą typologię, która odwołuje się do podwójnego znaczenia współczesnej autonomii ${ }^{120}$. Po pierwsze, jest to autonomia kultury i świecki obszar spraw (kultura, nauka, sztuka, gospodarka, polityka itd.), dla których zrozumienia, zarządzania i urzeczywistniania „hipoteza Boga” (Pierre Simon de Laplace, Julian Sorell Huxley) staje się coraz bardziej zbędna (ateizm naturalistyczny, materialistyczny, scjentystyczny, metodyczny czy agnostycyzm); po drugie, autonomia podmiotu, którego godność i wolność sprzeciwia się przyjęciu wszechmocnego Boga (humanistyczny ateizm wolności i polityczny ateizm wyzwolenia). Ateizm staje się tutaj opowiedzeniem się za wolnością i podmiotowością człowieka. „Tylko wtedy, gdy nie będzie Boga, człowiek może być rze-

115 Tenże, Bóg Jezusa Chrystusa, s. 15.

${ }^{116}$ Por. tamże, s. 26.

117 Tamże, s. 28.

${ }^{118}$ Por. tamże.

119 Por. tenże, Unsere Gottesbeziehung angesichts der sich wandelnden Gottesvorstellung, w: tenże, Glaube und Geschichte, Mainz 1970 [odtąd skrót: Unsere Gottesbeziehung], s. 108, s. 102; Möglichkeiten der Gotteserfahrung heute, w: tenże, Glaube und Geschichte, Mainz 1970, s. 121; Die Theologie angesichts des heutigen Atheismus, w: Gott-Frage und moderner Atheismus, red. J. Blank i in., Regensburg 1969, s. 73.

${ }^{120}$ Por. tenże, Bóg Jezusa Chrystusa, s. 30. 
czywiście i w pełni wolny”"121. Negacja Boga staje się zatem afirmacją człowie$\mathrm{ka}^{122}$.

W końcu istnieją również formy ateizmu, które wywodzą się z gorącego protestu przeciwko istnieniu ubóstwa, przemocy i wszelkiego zła na świecie. „Dla wielu ludzi egzystencjalnie są one bardziej rozstrzygające, niż teoretyczne czy ideologiczne kwestionowanie Boga"123. Wszechmogący Bóg, który widzi to całe zło, dopuszcza jego istnienie i nic nie czyni, aby mu zapobiec, byłby w gruncie rzeczy zaprzeczeniem samej idei miłosiernego Boga. Bóg, który swoim autorytetem niejako ręczyłby za zły i niesprawiedliwy porządek rzeczy, musiałby zostać pozbawiony tej władzy i odrzucony w imię wysiłków tworzenia nowego świata ${ }^{124}$.

Co ciekawe, widzimy, że współczesny ateizm w mniejszym stopniu opiera się na zdobyczach nauk eksperymentalnych z zakresu fizyki czy biologii; odwołuje się raczej do pojęć podmiotowości i wolności ${ }^{125}$.

Jednak współczesny zsekularyzowany świat, jak zauważa Kasper, ze swoją banalną jednowymiarowością sprawia, że ci, którzy pragną szukać Absolutu czy transcendencji, trafiają zazwyczaj na propozycje naiwnych i irracjonalnych urojeń lub wręcz fanatyzmu religijnego. Irracjonalność nowych poszukiwań religijnych takich, jak: astrologia, reinkarnacja, magia, gwałtowny rozwój sekt czy fenomen fundamentalistycznej i zbrojnej dżihadystycznej reislamizacji, stają się bardzo poważnym wyzwaniem naszych czasów ${ }^{126}$.

Nowożytny ateizm, w jego radykalnej formie negacji Boga, staje się dla chrześcijaństwa paradoksalnie szansą na podjęcie pogłębionej ewangelizacji świata. Tylko tam bowiem, gdzie człowiek w sposób bezwzględny opowiada się za Bogiem i Jego prawem, może zaistnieć tak zasadniczy odwrót od tych wartości. W bezkompromisowości współczesnego ateizmu pobrzmiewa zatem, pisze Kasper, coś nawiązującego swą radykalnością do pierwszych dwóch przykazań Bożych. Ateizm byłby w takim kluczu negatywem teologii, jej odmiennym biegunem, a także możliwością pogłębienia i oczyszczenia naszej wiary ${ }^{127}$.

W obliczu radykalnego zakwestionowania wiary chrześcijańskiej przez współczesny ateizm nie pomoże nam już słabowity, ogólny i niejasny teizm, lecz

${ }^{121}$ W. Kasper, Unsere Gottesbeziehung, s. 108.

${ }^{122}$ Por. tanże, Bóg Jezusa Chrystusa, s. 43.

123 Tamże, s. 30.

${ }^{124}$ Por. tenże, Unsere Gottesbeziehung, s. 110.

${ }^{125}$ Por. tenże, Bóg Jezusa Chrystusa, s. 26-66; Gottesglaube im Angesicht von säkularisierter und atheistischer Umwelt, w: Ein Gott für die Welt. Glaube und Sinnfrage in unserer Zeit, red. H. Wieh, München 1980, s. 37-51.

${ }^{126}$ Por. tenże, Tradierung und Vermittlung, s. 34; Was alles Erkennen übersteigt, Freiburg 1987, s. 30-31; Die Weitergabe des Glaubens in Ehe und Familie. Hirtenbrief an die Gemeinden der Diözese Rottenburg-Stuttgart zur österlichen Bußzeit 1990, „Kirchliches Amtsblatt der Diözese Rottenburg-Stuttgart“ 41(1990), nr 5, 2. Februar 1990, s. 34.

${ }^{127}$ Por. tenże, Unsere Gottesbeziehung, s. 112. 
tylko rozstrzygające świadectwo o żywym Bogu historii, który konkretnie dał się nam poznać przez Jezusa Chrystusa w Duchu Świętym. Ten właśnie Bóg Jezusa Chrystusa jest najdoskonalszym, eschatologiczno-ostatecznym zdefiniowaniem nieokreślonej otwartości człowieka. Staje się zatem najbardziej adekwatną chrześcijańską odpowiedzią na sytuację i wyzwanie współczesnego ateizmu ${ }^{128}$.

2. Ateizm mas jest zazwyczaj interpretowany $\mathrm{w}$ związku $\mathrm{z}$ zaawansowanymi procesami sekularyzacji ${ }^{129}$. Przebieg sekularyzacji charakteryzuje się pragnieniem wyzwolenia człowieka i społeczności z dominujących w poprzednich wiekach chrześcijańskich wzorców myślenia i zachowania. Człowiek zapragnął osądzać i traktować to, co ziemskie, za pomocą całkowicie ziemskich środków ${ }^{130}$.

$\mathrm{W}$ rozwoju tego typu myślenia, poza motywami kulturowo-historycznymi (nowoczesnymi formami emancypacji, wolności i godności jednostki), znaczną rolę odegrały także realne fakty dziejowe: podział Kościoła na Zachodzie w XVI wieku jako konsekwencja reformacji oraz narodziny i wzrost znaczenia nowoczesnego mieszczaństwa ${ }^{131}$.

Podzielone chrześcijaństwo nie było w stanie zagwarantować duchowej jedności i zachowania podstaw porządku społecznego ówczesnej Europy. Wręcz przeciwnie stało się zarzewiem wojen religijnych XVI/XVII wieku, które przywiodły społeczeństwo na krawędź ruiny ${ }^{132}$. Podjęto zatem próbę wypracowania nowej, jednoczącej wszystkich i dla wszystkich obowiązującej bazy, jednakże z pominięciem religii i wiary, które zadekretowano jako sprawy osobiste. Za podstawowe odniesienie nowego wspólnego porządku uznano jednoczący wszystkich ludzi rozum czy też racjonalnie rozpatrywany porządek natury ${ }^{133}$. Oświecenie zinterpretowało ten proces jako emancypację (wyzwolenie) i konieczność wzbudzenia w sobie odwagi do posługiwania się swoim własnym rozumem (dewiza oświeceniowa według Kanta: „Sapere aude!””) ${ }^{134}$.

Ten rozwój zbiegł się z awansem społecznym nowoczesnego mieszczaństwa. Powstało ono - przygotowane od XII wieku, a istotnie wsparte w okresie reformacji - przez emancypację od odziedziczonych politycznych, duchowych i społecznych mocy i formowało się na zasadzie autonomii człowieka, urzeczywistniającego siebie przez samą naukę, kwalifikacje, własne osiagnięcia i pracowitość.

128 Por. tamże, s. 389-390.

129 Por. tenże, Bóg Jezusa Chrystusa, s. 15. Szerzej na ten temat w: Säkularisierung, w: Staatslexikon. Recht - Wirtschaft - Gesellschaft, hrsg. v. der Görres-Gesellschaft, t. 4(1988) [odtąd skrót: Säkularisierung], s. 993-998.

${ }^{130}$ Por. tenże, Jesus der Christus, Mainz $1992^{11}$, s. 46.

131 Por. tamże, s. 46-48; Bóg Jezusa Chrystusa, s. 17-18.

132 Por. tenże, Bóg Jezusa Chrystusa, s. 18; Die Weitergabe des Glaubens, s. 15; Kirche und Freiheitsprozesse, s. 610.

${ }^{133}$ Por. tenże, Die Weitergabe des Glaubens, s. 15; Kirche und Freiheitsprozesse, s. 610.

134 Por. tenże, Die Weitergabe des Glaubens, s. 15. 
Trzeba w końcu uwzględnić także pojawienie się nowoczesnych dyscyplin naukowych, które przyniosły ze sobą nowy sposób postrzegania świata, niezależnego od jakichkolwiek czynników transcendentnych, a nawet stojący niekiedy w sprzeczności do zakładanego w Biblii i tradycji kościelnej pojmowania rzeczywistości ${ }^{135}$. Tak więc, pisze Walter Kasper, emancypacja życia społecznego z sakralnych ram doprowadziła do utraty idei Boga w jej uniwersalności, a religia stała się zwykłą częścią porządku socjalnego ${ }^{136}$.

3. Słowo „Bóg” oznacza we wszystkich językach świata i historii ludzkości ostateczne odwołanie do fundamentu istnienia oraz cel ostateczny człowieka i całej rzeczywistości. Jeśli braknie tego podstawowego odniesienia, grozi nam pogrążanie się w bezsensie ideologicznym i egzystencjalnym. Coś ma swój sens jedynie wówczas, kiedy odnajduje się w większej, sensownej panoramie całości. Wraz z utratą sensu całości, z zagubieniem wszystko podtrzymującej, wszystkim zawiadującej rzeczywistości Boga, w ostateczności każda poszczególna część staje się bezsensowna. Wszystko popada w bezmiar nicości, a koniec tego procesu wieńczy nadciągająca nieuchronność nihilizmu ${ }^{137}$. Wraz z tajemnicą Boga zanika także tajemnica człowieka, a śmierć Boga (F. Nietzsche) prowadzi nieuchronnie do śmierci człowieka ${ }^{138}$.

Reakcja Kościoła na wyzwanie współczesnych proc esów sekularyzacyjny ch poszła dwoma torami, pisze Walter Kasper. Najpierw do głosu doszły motywy i tendencje restauratywne ${ }^{139}$. W nowożytnej sekularyzacji dostrzegano jedynie upadek porządku, odwrócenie się od Boga i chrześcijaństwa oraz zapowiedź nadciagającej katastrofy ${ }^{140}$. Programowi sekularyzacji przeciwstawiono kontrprogram restauracji. Rozwój wydarzeń przyniósł następnie narodziny progresywnego kierunku tzw. „teologii sekularyzacji” lat pięćdziesiątych i sześćdziesiątych XX wieku (F. Gogarten, J.B. Metz w nawiązaniu do myśli G.W.F. Hegla, M. Webera czy E. Troeltscha). Utrzymywał on, że nowożytna sekularyzacja jest konsekwencją chrześcijaństwa, a nawet w pewnym sensie jego ziemskim urzeczywistnieniem. Biblijne rozróżnienie pomiędzy Bogiem a światem otworzyło drogę do nowego ujmowania świata jako bytu niezależnego i kierującego się swym własnym i w pewnym sensie niezależnym porządkiem ${ }^{141}$. Chciano rozróżnić pomiędzy usprawiedliwioną sekularyzacją

${ }^{135}$ Por. W. Kasper, Bóg Jezusa Chrystusa, s. 18.

${ }^{136}$ Por. tenże, Säkularisierung, s. 995.

${ }^{137}$ Por. tenże, Bóg Jezusa Chrystusa, s. 19.

${ }^{138}$ Por. tamże, s. 20.

${ }_{139}$ Por. tenże, Verkündigung als Provokation, w: tenże, Glaube und Geschichte, Mainz 1970, s. 228-229.

${ }^{140}$ Por. tenże, Bóg Jezusa Chrystusa, s. 16.

${ }^{141}$ Por. tamże. 
a nieusprawiedliwionym sekularyzmem. Ten typ teologii umożliwił wprawdzie, w przeciwieństwie do tendencji restauratywnych, chrześcijańską akceptację nowożytnych procesów emancypacyjnym i wolnościowych, niemniej jednak w obliczu konkretnego rozwoju historii pozostał czymś abstrakcyjnym. Przede wszystkim, pisze Kasper, świat zsekularyzowany przestaje być chrześcijański, a wobec wiary i Kościoła pozostaje indyferentny lub wrogi ${ }^{142}$.

Także trzeci model, polegający na postrzeganiu czasów nowożytnych jako aktu samopotwierdzenia się człowieka przeciwko przemożnej, zniewalającej człowieka transcendencji i skostniałym, reakcyjnym strukturom kościelnym (H. Blumenberg), uznaje niemiecki kardynał za rozwiązanie zupełnie niezadowalające ${ }^{143}$.

Jedynie program tzw. „teologicznej teologii”"144 może być adekwatną odpowiedzią Kościoła na nowożytne procesy sekularyzacji i masowy ateizm. Walter Kasper pisze:

Jeśli mówienie o Bogu transcenduje wszelki obszar wewnątrzświatowy, także i wymiar polityczny, wówczas wraz z transcendencją Boga strzeże także transcendencji ludzkiej osoby, to znaczy wolności człowieka i jego niezbywalnych praw, jako osoby ludzkiej. Zatem ze względu na Boga, jak i ze względu na człowieka „powrót do sacrum" jest istotnym zadaniem na dziś. W obliczu wielu redukcjonistycznych programów teologicznych nie jest już, niestety, żadnym pleonazmem, kiedy się stwierdza, że teologia teologiczna, zwłaszcza dziś, jest nakazem chwili i jedyną stosownie do stanu rzeczy odpowiedzią na współczesny ateizm ${ }^{145}$.

Pogłębiając nieco postulat Kaspera dotyczący „teologii teologicznej”, trzeba zauważyć, że niemiecki kardynał kładzie wielki nacisk na zakorzenienie nauki o wierze w jej eklezjalnym Sitz im Leben, w tym, czym Kościół jest i w co wierzy $^{146}$ (por. KO 8), a przede wszystkim w samym Bogu, który udziela się nam przez Jezusa Chrystusa w Duchu Świętym ${ }^{147}$. Nie możemy, pisze on, zawężać się do tworzenia teologii antropologicznej, socjologicznej czy psychologicznej, lecz musimy podjąc trud uprawiania teologii świadomie teologicznej, która zakorzeniona głęboko na gruncie wiary i Tradycji eklezjalnej byłaby jednocześnie w stanie podjąć wyzwanie dialogu i komunikacji ze współczesną myślą i kultura, a przez to składała wobec wszystkich świadectwo (apologia) o chrześcijańskiej nadziei (1 P 3,15) $)^{148}$. Według Kaspera właściwym przedmiotem teologii jest za-

${ }^{142}$ Por. tamże.

${ }_{143}^{143}$ Por. tamże.

${ }^{144}$ Por. tamże, s. 25, 390.

145 Tamże, s. 25.

${ }^{146}$ Por. Sobór Watykański II, Konstytucja dogmatyczna o objawieniu Bożym Dei verbum, w: tenże, Konstytucje, dekrety, deklaracje, Poznań 2002, s. 350-363.

${ }^{147}$ Por. tenże, Zur Situation der katholischen Theologie in der Bundesrepublik Deutschland, w: Kirche in Europa, red. F. Wetter, Düsseldorf 1989, s. 75; Bóg Jezusa Chrystusa, s. 25, 390-391.

${ }^{148}$ Por. tenże, Zur Situation der katholischen Theologie in der Bundesrepublik Deutschland, w: Kirche in Europa, red. F. Wetter, Düsseldorf 1989, s. 75. 
tem nie tyle sama wiara Kościoła, ile poświadczona w jej tajemnicach prawda samoobjawiającego się Boga. Ten właśnie związek czyni z teologii prawdziwą „theo-logię” i wyraża najgłębiej jej potrzebę i rolę w Kościele ${ }^{149}$.

4. Nowożytne procesy sekularyzacyjne nie zdołały oczywiście całkowicie usunąc chrześcijaństwa oraz religii i wiary jako takich z horyzontu postrzegania rzeczywistości przez współczesnego człowieka ${ }^{150}$. Nie potwierdziła się teoria o absolutnym triumfie sekularyzacji wobec religii. Socjologowie religii mówią raczej od pewnego czasu o ,przetrwaniu” i „powrocie” religii (persistence of religion $)^{151}$. Wobec otaczającej nas zsekularyzowanej rzeczywistości nadrzędnym celem pastoralnej misji Kościoła powinno stać się nie tyle tanie dopasowywanie się do zmieniających się warunków, ile ponowne odkrywanie i wskazywanie wymiaru tego, co boskie. Kościół ma za zadanie strzec tajemnicy Boga w świecie i w życiu poszczególnych ludzi oraz całych społeczeństw, a zarazem spajać w jedno religię i świecką społeczność, przy zachowaniu odrębności obu tych obszarów ${ }^{152}$. Ma to czynić w duchu nowego humanizmu, za przykładem świętego papieża Jana Pawła II, starając się wypełnić nakaz nowej ewangelizacji jako przezwyciężenie schizmy pomiędzy Kościołem a współczesną kulturą ${ }^{153}$. To oznacza według Kaspera: „Musimy odważyć się podjąć dzieło nowej ewangelizacji; ona zaś zakłada ponowną inkulturację chrześcijaństwa" ${ }^{154}$.

Chodzi tutaj o ewangelizację w konkretnych warunkach naszej obecnej historii. „Ewangelia o zbawieniu człowieka i świata niesie ze sobą uzdrowienie $\mathrm{z}$ ran zadanych nam przez naszą współczesną cywilizację. Może ona twórczo podjać i dowartościować pozytywne efekty nowożytnych przemian, a zarazem uchronić współczesność przed autodestrukcją"155. Wydaje się, że program wiary odpowiedzialnej, która w nawiązaniu do projektu św. Anzelma z Canterbury ( $f i-$ des quaerens intellectum), jest zawsze gotowa do obrony wobec każdego, kto domaga się uzasadnienia nadziei, która w nas jest (por. 1 P 3, 15), w takich warunkach ogromnie zyskuje na aktualności.

5. Wyrazem, a jednocześnie rodzajem podsumowania praktycznego zorientowania teologii kardynała Kaspera na zagadnienia współczesności jest jego teza

${ }^{149}$ Por. W. Kasper, Zur Situation, s. 14.

${ }^{150}$ Por. tenże, Säkularisierung, s. 997; Natur-Gnade-Kultur, s. 87.

${ }^{151}$ Por. tenże, Evangelisierung und Neuevangelisierung. Überlegungen zu einer neuen pastoralen Perspektive, w: Verantwortung für den Glauben: Beiträge zur Fundamentaltheologie und Ökumenik. Festschrift für H. Fries, red. P. Neuner, H. Wagner, Freiburg im Breisgau 1992 [odtąd skrót: Evangelisierung], s. 237; Autonomie und Theonomie, s. 187.

${ }^{152}$ Por. tenże, Natur-Gnade-Kultur, s. 87; Säkularisierung, s. 997-998; Evangelisierung, s. 239.

${ }^{153}$ Por. tenże, Evangelisierung, s. 239; Warum noch Mission?, w: tenże, Glaube und Geschichte, Mainz 1970, s. 271-274.

${ }^{154}$ Tenże, Natur-Gnade-Kultur, s. 88; por. tenże, Evangelisierung, s. 236-238.

155 Tenże, Evangelisierung, s. 238. 
o świecie jako przestrzeni Ewangelii (Welt als Ort des Evangeliums). Pozytywne postrzeganie świata przez chrześcijan powinno opierać się na prawdzie, że Bóg stworzył świat i człowieka z miłości, odkupił go i przeznaczył do osiagnięcia eschatologicznej pełni, w której swoje miejsce znajdą również nasze wysiłki budowania sprawiedliwej i bardziej ludzkiej rzeczywistości, pisze niemiecki kardynał ${ }^{156}$.

W takim kontekście dotychczasowy model, opierający się ścisłym rozróżnieniu sacrum i profanum, którego konsekwencją stała się izolacja i wyobcowanie Kościoła we współczesnym świecie i społeczeństwie, nie ma już racji bytu ${ }^{157}$. Świat powinien być postrzegany przez chrześcijan raczej jako locus theologicus, to znaczy jako miejsce, gdzie człowiek spotyka się z orędziem Ewangelii ${ }^{158}$. Jest to swoiste rozszerzenie opracowania loci theologici, jakie znamy z dzieł Melchiora Cano ${ }^{159}$.

Kasper pisze, że świat przestał być dla współczesnego człowieka odbiciem stałego i skostniałego porządku. Jest nam nie tylko dany, ale i zadany, aby współkształtować go w procesach dziejowych. Takie pojmowanie otaczającej nas rzeczywistości pociaga za sobą określone konsekwencje także w rozumieniu przesłania Ewangelii. Prawda Chrystusowa, głoszona przez Kościół, toruje sobie drogę do serc i umysłów słuchaczy wciąż na nowo i w ciągle zmieniających się warunkach zewnętrznych ${ }^{160}$. Kasperowi chodzi o nieustanny proces ewangelijnego aggiornamento, o ciagła potrzebę „mediacji”, przekazywania niezmiennej prawdy w nieustannie ewoluującą i zmieniającą się rzeczywistość (die Situationsgerechtheit des Evangeliums ${ }^{161}$. Oczywiście nie ma tutaj mowy o tanim dopasowywaniu się do ducha czasu czy jakimś teologicznym okazjonalizmie, który stałby w jaskrawej sprzeczności z dziedzictwem żywej Tradycji Kościoła ${ }^{162}$.

Dobrym przykładem na znalezienie właściwego balansu pomiędzy jednością i niezmiennością Ewangelii a różnorodnością sposobów jej głoszenia może być kościelne studium prawdy inkarnacyjnej i jej sformułowanie w dogmacie chalcedońskim (451), pisze Walter Kasper. Orzeczenie Magisterium z Chalcedonu przez zastosowanie do Syna Bożego formuły: „bez zmieszania, bez rozdzielania”, zachowało prawdę objawioną o zjednoczeniu i odrębności dwóch natur, boskiej i ludzkiej, w Chrystusie ${ }^{163}$. „Nigdy nie zanikły różnice natur przez ich zjednocze-

${ }^{156}$ Por. tenże, Gottes Zeit für die Menschen. Besinnung zum Kirchenjahr, Freiburg 1987, s. 41.

${ }^{157}$ Por. tenże, Neue Akzente im dogmatischen Verständnis des prieseterlichen Dienstes, „Concilium“ (D) 5(1969), s. 165; Die Funktion des Priesters in der Kirche, w: tenże, Glaube und Geschichte, Mainz 1970, s. 373.

${ }^{158}$ Por. tenże, Die Welt, s. 217; Die Methoden, s. 43, przyp. 14.

159 Por. tenże, Die Welt, s. 209.

${ }^{160}$ Por. tamże, s. 222.

${ }^{161}$ Por. tamże.

${ }^{162}$ Por. tamże; J. Morawa, Die Communio-Kirche, s. 125.

${ }^{163}$ Por. W. Kasper, Die Welt, s. 211-217; Säkularisierung, s. 997; J. Morawa, Die Communio-Kirche, s. 126. 
nie, ale została zachowana właściwość obu, tworzących jedną osobę i jedną hipostazę"164. Osoba Jezusa Chrystusa, który jest „bez zmieszania i bez rozdzielenia" prawdziwym Bogiem i prawdziwym człowiekiem, rzuca nowe światło na chrześcijańskie pojmowanie wzajemnego odniesienia Boga i świata: ściślejsza jedność stworzenia z Bogiem prowadzi zarazem do pogłębienia jego autonomii (Karl Rahner) ${ }^{165}$.

Wcielenie Syna Bożego oznacza w takim kontekście, że świat i człowiek, właśnie w ich „światowości” i człowieczeństwie stają się przestrzenią Ewangelii ${ }^{166}$. Taki sposób pojmowania rzeczywistości niesie ze sobą określone konsekwencje dla Kościoła. Jeśli świat jest także miejscem spotkania z orędziem Dobrej Nowiny, to Kościół, który stoi w służbie Ewangelii, nie może być już tylko w stosunku do świata nauczycielem, ale powinien wsłuchiwać się w jego głos, rozróżniać ziarno od plew, popierać wszelkie dobre inicjatywy, a nawet uczyć się od niego ${ }^{167}$. Oczywiście nie jest to równoznaczne z pragnieniem zeświecczenia Kościoła. Walter Kasper pisze, że wierzący muszą posiąść dzisiaj umiejętność „rozróżniania chrześcijańskości” (Romano Guardini), aby depozyt wiary i głoszony w Kościele kerygmat nie doznały uszczerbku ${ }^{168}$. Twierdzi on, że współczesny kryzys katolicyzmu w Niemczech polega właśnie na owym braku umiejętności właściwego rozróżnienia pomiędzy tym, co prawdziwie chrześcijańskie, a tym, co światowe ${ }^{169}$. Dostrzegając możliwe zagrożenia, podkreśla jednak z moca, że dla właściwie pojętego modelu odniesienia ,śsiat-Ewangelia-Kościół", który realizuje się w zamyśle Welt als Ort des Evangeliums, nie ma w obecnym czasie dobrej alternatywy ${ }^{170}$.

\section{W miejsce zakończenia}

Wydaje się, że nie można zaprzeczyć, iż teologiczna myśl Waltera Kaspera jest głęboka, a wiele przemyśleń oraz wniosków, jakie kardynał wysnuwa z obserwacji współczesnego Kościoła, jego teologii, ale i dzisiejszego świata, do którego wspólnota uczniów Chrystusa kieruje swe orędzie, należy uznać za trafne.

Postulat dialogicznej otwartości teologii jest bez wattpienia słuszny. Prawdą jest, że chrześcijanin powinien uważnie odczytywać znaki czasu i wsłuchiwać się w „proroctwo” świata, aby uwzględniając pytania współczesności, lepiej i głę-

${ }^{164}$ BF VI, 8 .

${ }^{165}$ Por. W. Kasper, Säkularisierung, s. 997.

${ }^{166}$ Por. tenże, Die Welt, s. 215.

${ }^{167}$ Por. tamże, s. 210-211.

${ }^{168}$ Por. tamże, s. 211.

${ }^{169}$ Por. tenże, Zur Lage der katholischen Kirche Deutschlands, „Internationale katholische Zeitschrift Communio“ 17(1988), nr 1, s. 66.

${ }^{170}$ Por. tenże, Die Welt, s. 217. 
biej rozumieć samą Ewangelię oraz przepajać jej duchem konkretne przejawy naszej rzeczywistości. Owo „proroctwo” nawiązuje zresztą ściśle do wspomnianej wyżej tezy Kaspera o świecie jako przestrzeni Ewangelii (Welt als Ort des Evangeliums). Chodzi o pozytywne postrzeganie świata przez chrześcijan, które powinno opierać się na prawdzie, że Bóg stworzył świat i człowieka z miłości, odkupił go i przeznaczył do osiagnięcia eschatologicznej pełni ${ }^{171}$, a oderwanie zbawienia od rzeczywistości świata (weltloses Heil) prowadzi z konieczności do oderwania świata od nadziei zbawienia (heillose Welt) $)^{172}$.

Słuszny wydaje się ponadto postulat Kaspera o potrzebie korekty przedsoborowego modelu pojmowania Kościoła i świata, opierającego się na ścisłym rozróżnieniu pomiędzy sacrum i profanum, którego konsekwencją stała się izolacja i wyobcowanie Kościoła we współczesnym świecie i społeczeństwie ${ }^{173}$.

Kłopot polega jednak na tym, że owo „proroctwo” świata, o którym mówimy, jest w bardzo wielu przypadkach całkiem niejasne i niejednoznaczne. Kasper chce nas wprawdzie nauczyć patrzeć na świat jako na locus theologicus, to znaczy na miejsce, gdzie człowiek spotyka się z orędziem Ewangelii, niemniej jednak historia (choćby ta najnowsza, posoborowa) wskazuje, jak skomplikowane to przedsięwzięcie i jak wiele błędów popełniamy przy jego realizacji. Wydaje się czasem, że Kasper postrzega współczesny świat zbyt jednostronnie, nie uwzględniając zabiegów i starań ośrodków kłamstwa czy relatywizmu, które występują mniej lub bardziej jawnie nie tylko przeciw chrześcijaństwu, ale wręcz przeciw uświęconemu wielowiekową tradycją porządkowi społeczeństwa, wychowania, rodziny i wartości.

Optymistyczna (naiwna?) wersja postrzegania świata i dialogicznej otwartości teologii w dialogu z nim jako zasada szkoły tybingeńskiej, która towarzyszyła Walterowi Kasperowi na wszystkich etapach jego kościelnej aktywności, odciska piętno także na kształcie przesłania jego najnowszego dzieła Miłosierdzie. Ta książka, która od początku budziła sprzeczne oceny i opinie ${ }^{174}$, stała się niejako wyrazem, a jednocześnie pewnym rodzajem podsumowania praktycznego zorientowania teologii niemieckiego kardynała na pytania i problemy, które niesie ze sobą współczesność.

Zatem, chociaż ta ostatnia monografia Kaspera nadawałaby się na temat nowego, osobnego opracowania, spróbujemy, choć pokrótce, nawiązać na tym miej-

\footnotetext{
${ }^{171}$ Por. tenże, Gottes Zeit für die Menschen. Besinnung zum Kirchenjahr, Freiburg 1987, s. 41.

172 Por. tenże, Diener eurer Freude, „Berufung. Zur Pastoral der geistlichen Berufe“, z. 36, Freiburg 1998, s. 7.

${ }^{173}$ Por. tenże, Neue Akzente im dogmatischen Verständnis des prieseterlichen Dienstes, „Concilium“ (D) 5(1969), s. 165; Die Funktion des Priesters in der Kirche, w: tenże, Glaube und Geschichte, Mainz 1970, s. 373.

${ }_{174}$ Przykładem niech będzie polemiczna do stanowiska Kaspera publikacja kardynała Paula Josefa Cordesa Geistige Kommunion. Befreit vom Staub der Jahrhunderte (Kisslegg 2014).
} 
scu do niektórych tez w niej zawartych, a odnoszących się przede wszystkim do poruszanych w naszym tekście zagadnień. Ukażemy w ten sposób, jak wierność pryncypiom Tybingi i praktyczna otwartość teologii Waltera Kaspera (szczególnie w jej pastoralnym wymiarze) prowadzą do postrzegania niemieckiego kardynała w Kościele jako postaci ogromnie kontrowersyjnej.

Mówiąc o miłosierdziu, Kasper stwierdza w swej publikacji, że owo centralne dla Biblii, a dla współczesnego doświadczenia rzeczywistości ogromnie aktualne zagadnienie ${ }^{175}$ nie doczekało się do tej pory należytego pogłębienia teologicznego. Jeśli jest ono obecne $\mathrm{w}$ słownikach $\mathrm{i}$ podręcznikach teologii dogmatycznej, to jedynie marginalnie. Jest ono omawiane jako jeden $\mathrm{z}$ wielu przymiotów Boga - i najczęściej krótko, dopiero po innych, tych, które wynikają z metafizycznej istoty Boga. W nowszych podręcznikach zazwyczaj w ogóle go nie znajdziemy, a jeśli się już pojawia, to jako temat poboczny. Ten deficyt teologicznej teorii sprawił, że przesłanie miłosierdzia zostało zredukowane do „miękkiej” działalności pastoralnej i duchowości oraz pozbawione jasnego profilu ${ }^{176}$.

Dotychczasowa przewaga refleksji metafizycznej (przy całej jej słuszności i doniosłości) wobec braku należytego uwzględnienia nowszych zagadnień, odnoszących się do współczesnych ujęć personalistycznych czy dowartościowania procesów dziejowych i historycznych przemian w badaniach teologicznych, doprowadziły do tego, że pośród metafizycznych przymiotów Boga nie ma odpowiedniego miejsca dla miłosierdzia, które wynika przecież nie tyle z istoty metafizycznej, ile z historycznej ofiary samego Boga ${ }^{177}$. Kasper pisze:

Równie mało miejsca jest tam również dla świętości i gniewu Boga, czyli Jego oporu wobec zła. Zatem fakt, że miłosierdzie popadło w zapomnienie, nie stanowi jedynie marginalnego problemu nauki o Bogu. Stawia nas to raczej wobec zasadniczego problemu określania istoty i przymiotów Boga w ogóle oraz przed koniecznością nadania nowego kierunku dogmatyce ${ }^{178}$.

Dzisiejszy kryzys gospodarczy i finansowy jest, jak podkreśla niemiecki kardynał, także kryzysem antropologicznym i duchowym. Stąd, abyśmy nie zapomnieli pytać o to, co naprawdę wartościowe i z ludzkiego punktu widzenia warte życia, Kościół musi mieć coś do powiedzenia w zasadniczych kwestiach gospodarczych, społecznych i etycznych. Musi umieć zwracać tam uwagę na Boże i ludzkie miłosierdzie. Musi „mieszać się do życia społecznego”, nie dla własnego dobra i we własnym interesie, lecz w interesie ludzi oraz dla obrony człowieczeństwa w społeczeństwie ${ }^{179}$. Co do tego, że sprawiedliwość ma znaczenie dla

\footnotetext{
${ }^{175}$ Por. W. Kasper, Miłosierdzie, s. 27.

176 Por. tamże, s. 20-21.

${ }^{177}$ Por. tamże, s. 21.

178 Tamże, s. 21-22.

179 Por. tamże, s. 200.
} 
właściwego ładu społecznego, w zasadzie panuje powszechna zgoda, niemniej jednak wiele osób zgłasza zastrzeżenia, gdy chodzi o znaczenie miłosierdzia, które interpretuje się jako typową cnotę chrześcijańską niemającą w zasadzie czego szukać w projekcie społeczeństwa świeckiego. Tymczasem, pisze Kasper, ludzie widzą,

że globalizacja i ujawniające się w jej ramach tendencje neokapitalistyczne (w których jednostki często z bezwstydną chciwością bogacą się kosztem wielu ludzi), stawiają przed idea państwa socjalnego nowe wyzwania. A to stanowi z kolei wyzwanie również dla społecznej nauki Kościoła. Pytanie brzmi: Co chrześcijanie w tej sytuacji mogą uczynić na rzecz społeczeństwa socjalnego i miłosiernego? Jak może i jak powinna dalej się rozwijać kościelna nauka społeczna? Czy w tej sytuacji chrześcijańskie miłosierdzie może na nowo zyskać na znaczeniu, wykraczając poza niezmiennie fundamentalną sprawiedliwość? ${ }^{180}$

Postulat Kaspera, dotyczący potrzeby realizowania chrześcijańskiego przykazania miłości bliźniego w realiach dzisiejszego świata ${ }^{181}$, prowadzi go jednak do spornego ujęcia zagadnienia warunków dopuszczenia do sakramentów Kościoła osób rozwiedzionych (miłosierdzie w Prawie kanonicznym) ${ }^{182}$. Kładzie on nacisk na wczucie się w wyjątkowość sytuacji każdego człowieka i stosowanie zasady epikii. Niemiecki kardynał pisze:

Już Arystoteles wiedział, że ogólne prawa nie pozwalają w sposób adekwatny rozwiązać wszystkich bardzo złożonych przypadków indywidualnych. A zatem epikia musi wypełnić luki prawa i jako wyższa sprawiedliwość nie uchylać obiektywnej normy prawnej w indywidualnym przypadku, lecz zastosować ją w mądry sposób tak, że jej zastosowanie $w$ danym przypadku okaże się rzeczywiście sprawiedliwe, nie zaś niesprawiedliwe. [...] Ludzkie prawa mogą być wyłącznie ut in pluribus, to znaczy obowiązujące w większości przypadków, i ze względu na swój ogólny charakter nigdy nie będą w stanie rozwiązać wszystkich indywidualnych przypadków, często bardzo złożonych. Dlatego epikia nie łamie prawa; jest raczej wyższą formą sprawiedliwości ${ }^{183}$.

Tyle pokrótce o niektórych tezach Waltera Kaspera, odnoszących się do jego pojmowania problematyki miłosierdzia. Jest to bez wątpienia pojmowanie, które pragnie uwzględnić wiele $\mathrm{z}$ idei i sposobów rozumienia tego zagadnienia we współczesnej kulturze, prawie i filozofii. Tymczasem podnoszą się głosy, że takie stawianie sprawy, to nie tyle dialog ze współczesnym światem, ile raczej bezkrytyczne dostosowywanie się do niego.

W dyskusji, dotyczącej propozycji dopuszczenia do sakramentów osób rozwiedzionych, możemy na forum polskojęzycznym znaleźć takie sformułowania, jak:

180 Tamże, s. 204.

${ }^{181}$ Por. tamże, s. 161.

182 Por. tamże, s. 191-197.

${ }^{183}$ Tamże, s. 194-195. 
Gdyby doszło do przyjęcia postulatu Kaspera, proponowanego dla wąskiej grupy potrzebujących, szybko zobaczylibyśmy jak znika w Kościele katolickie nauczanie o grzechu, Eucharystii, małżeństwie. [...] Niebezpieczeństwo [propozycji Kaspera] polega na wyjęciu ze skarbca Kościoła jednego ważnego elementu i uczynieniu z niego jedynej wykładni całej doktryny. Tak dzieje się tu właśnie z miłosierdziem. Dodać należy też wykrzywianie jego rozumienia w stylu liberalnych mediów. Miłosierdzie nie jest powiedzeniem: „Nie obchodzą mnie Twoje grzechy, idź czyń podobnie”, czyli na przykład cudzołóż. Miłosierdzie jest przebaczeniem Boga, dającym nadzieję zbawienia. [...] $\mathrm{W}$ tej sytuacji jest to dostosowanie do świata - nie ma co do tego wątpliwości. Nie wiem, jakie intencje ma kardynał, ale praktycznie zmierza on do rozpuszczenia Kościoła w złych praktykach nowoczesnego świata. [...] propozycja kard. Kaspera, choć ogłoszona jako duszpasterska, jest w rzeczywistości obejściem prawd wiary, ale i kompletnym zapomnieniem dziedzictwa Jana Pawła II i Soboru Watykańskiego II, który wzywa nas do świętości w każdej sytuacji życiowej ${ }^{184}$.

Jak kardynał Walter Kasper broni swego stanowiska wobec wzmiankowanych zarzutów? Byłby to z pewnością ciekawy materiał na następne opracowanie, tym bardziej że mieściłby się $w$ ramach charakteryzujących powyższe rozważania: dialog ze współczesnością i jej problemami z punktu widzenia teologa osadzonego w tradycji Kościoła, ale zarazem otwartego na wciąż nowe wyzwania, które przynosi nam ze sobą czas oraz rozwój człowieka i świata.

\section{Dialogic Openness of the Cardinal Walter Kasper's theology as a Participation in the Heritage of the Catholic School of Tübingen}

\section{Summary}

Our masters, next to which we grew up, and certain environments that have formed - on many levels - not only our consciousness, but even the methodology of our thinking and activities, play a very significant role in the shaping the way we look at and understand the world, and the ideas, which we adhere to. Cardinal Walter Kasper repeatedly relied in his works on his spiritual relationship with the principles of Catholic school in Tübingen of the nineteenth century, considering it as an outstanding model for attachment to ecclesiastical tradition and at the same time for the openness to the dialogue with the contemporary world. This text presents one of the theological principles of the school in Tübingen - dialogical openness of the theology to the contemporary issues - in the work and thought of Cardinal Walter Kasper.

\section{Keywords}

Walter Kasper, the School of Tübingen, contemporaneity, openness, dialog

${ }^{184}$ Jest to fragment wywiadu, jaki Marta Brzezińska-Waleszczyk z portalu Fronda.pl przeprowadziła z Tomaszem Rowińskim przy okazji rozpoczętego synodu poświęconego rodzinie. Został on zatytułowany: Kasper zmierza do rozpuszczenia Kościoła $w$ złych praktykach nowoczesnego świata, [online] http://christianitas.org/news/kasper-zmierza-do-rozpuszczenia-kosciola-w-zlychpraktykach-nowoczesnego-swiata/ [dostęp: 16.03.2015]. 


\section{Słowa kluczowe}

Walter Kasper, szkoła tybingeńska, współczesność, otwartość, dialog

\section{Bibliografia}

Brzezińska-Waleszczyk M., Kasper zmierza do rozpuszczenia Kościoła $w$ ztych praktykach nowoczesnego świata, [online] http://christianitas.org/news/kasper-zmierza-do-roz puszczenia-kosciola-w-zlych-praktykach-nowoczesnego-swiata/ [dostęp: 16.03.2015].

Bubel G., Walter Kasper. Między tradycja a nowoczesnościa, w: Leksykon wielkich teologów XX/ XXI wieku, red. J. Majewski, J. Makowski, Warszawa 2003, s. 147-159.

Colombo P., Szkoła tybingeńska, w: Historia teologii, t. 4: Epoka nowożytna, red. G. Angelini, G. Colombo, M. Vergottini, tłum. W. Szymona, Kraków 2008, s. 293-328.

Cordes P.J., Geistige Kommunion. Befreit vom Staub der Jahrhunderte, Kisslegg 2014.

Cornelissen R.J.F., Offenbarung und Geschichte, Essen 1972, Geleitwort von W. Kasper.

Drumm J., Bibliographie Walter Kasper 1960-1992, w: Dogma und Glaube. Bausteine für eine theologische Erkenntnislehre, red. E. Schockenhof, P. Walter, Mainz 1993, s. 294-333.

Geiselmann J.R., Die katholische Tübinger Schule. Ihre theologische Eigenart, Freiburg im Breisgau 1964.

Geiselmann J.R., Geist des Christentums und des Katholizismus, t. 5: Deutsche Klassiker der katholischen Theologie aus neuerer Zeit, Mainz 1940.

Geiselmann J.R., Lebendiger Glaube aus geheiligter Überlieferung, Mainz 1942.

Geiselmann J.R., Die Anthropologie J.A. Möhlers, Freiburg im Breisgau 1955.

Geiselmann J.R., Die lebendige Überlieferung als Norm des christlichen Lebens, Freiburg im Breisgau 1959.

Kasper W., Das Absolute in der Geschichte. Philosophie und Theologie der Geschichte in der Spätphilosophie Schellings, Mainz 1965.

Kasper W., Die Methoden der Dogmatik. Einheit und Vielheit, München 1967.

Kasper W., Gott in der Geschichte, w: Gott heute. 15 Beiträge zur Gottesfrage, red. N. Kutschki, Mainz-München 1967, s. 139-151.

Kasper W., Kirche nach dem Konzil, w: Christliche Verantwortung. Eine ökumenische Bestandsaufnahme zeitgemäßer Ethik, red. V. Hochgrebe, Würzburg 1968, s. 306-316.

Kasper W., Der Glaube und die Gläubigen heute, „Militärseelsorge“ 10 (1968), s. 208-221.

Kasper W., Die Theologie angesichts des heutigen Atheismus, w: Gott-Frage und moderner Atheismus, red. J. Blank i in., Regensburg 1969, s. 73-104.

Kasper W., Neue Akzente im dogmatischen Verständnis des priesterlichen Dienstes, „Concilium“ (D) 5(1969), s. 164-170.

Kasper W., Die Funktion des Priesters in der Kirche, „Geist und Leben“ 42(1969), nr 2, s. 102-116.

Kasper W., Krise und Wagnis des Glaubens im Leben des Priesters, „Geist und Leben“ 42(1969), nr 4, s. 244-250. 
Kasper W., Die Heilssendung der Kirche in der Gegenwart, Mainz 1970.

Kasper W., Verständnis der Theologie damals und heute, w: W. Kasper, Glaube und Geschichte, Mainz 1970, s. 9-32.

Kasper W., Die Freiheit als philosophisches und theologisches Problem in der Philosophie Schellings, w: W. Kasper, Glaube und Geschichte, Mainz 1970, s. 33-47.

Kasper W., Kirche und Theologie unter dem Gesetz der Geschichte, w: W. Kasper, Glaube und Geschichte, Mainz 1970, s. 49-66.

Kasper W., Grundlinien einer Theologie der Geschichte, w: W. Kasper, Glaube und Geschichte, Mainz 1970, s. 67-100.

Kasper W., Unsere Gottesbeziehung angesichts der sich wandelnden Gottesvorstellung, w: W. Kasper, Glaube und Geschichte, Mainz 1970, s. 101-119.

Kasper W., Möglichkeiten der Gotteserfahrung heute, w: W. Kasper, Glaube und Geschichte, Mainz 1970, s. 120-143.

Kasper W., Die Welt als Ort des Evangeliums, w: W. Kasper, Glaube und Geschichte, Mainz 1970, s. 209-223.

Kasper W., Verkündigung als Provokation, w: W. Kasper, Glaube und Geschichte, Mainz 1970, s. 224-242.

Kasper W., Warum noch Mission?, w: W. Kasper, Glaube und Geschichte, Mainz 1970, s. 259-274.

Kasper W., Die Verwirklichung der Kirche in Ehe und Familie. Überlegungen zur Sakramentalität der Ehe, w: W. Kasper, Glaube und Geschichte, Mainz 1970, s. 330-354.

Kasper W., Die Funktion des Priesters in der Kirche, w: W. Kasper, Glaube und Geschichte, Mainz 1970, s. 371-387.

Kasper W., Amt und Gemeinde, w: W. Kasper, Glaube und Geschichte, Mainz 1970, s. $388-414$.

Kasper W., Zum Problem der Rechtgläubigkeit in der Kirche von morgen, w: Kirchliche Lehre-Skepsis der Gläubigen, red. W. Kasper, F. Haarsma, F.X. Kaufmann, Freiburg im. Breisgau 1970, s. 37-96.

Kasper W., Die Funktion der Theologie in der Kirche, w: Die Zukunft der Theologie in der Kirche. Berichtband des Concilium-Kongresses 1970, Zürich 1971, s. 45-52.

Kasper W., Das priesterliche Dienstamt, „Diakonia - Der Seelsorger“ 4(1971), s. 222$-232$.

Kasper W., Einführung in den Glauben, Mainz 1972.

Kasper W., Die Zukunft des Glaubens. Thesen zur Krise der westdeutschen Synode, „Lebendige Seelsorge“ 1973, s. 14-19.

Kasper W., Rechenschaft vom Glauben heute, „Universitas“ 28(1973), s. 1301-1307.

Kasper W., Priesterbildung und Priesterausbildung heute. Theologische Überlegungen zu den neusten Umfrageergebnissen, „Theologische Quartalschrift“ 155(1975), s. 300-318 .

Kasper W., Karl Adam. Zu seinem 100. Geburtstag und 10. Todestag, „Theologische Quartalschrift" 156(1976), nr 4, s. 251-258.

Kasper W., Die Kirche angesichts der Herausforderungen der Postmoderne, „Stimmen der Zeit“" 215(1997), s. 651-664. 
Kasper W., Christliche Freiheit und neuzeitliche Autonomie, w: Menschenwürdige Gesellschaft, hrsg. v. d. Salzburger Hochschulwochen, Graz 1977, s. 73-110.

Kasper W., Die schädlichen Nebenwirkungen des Priestermangels, „Stimmen der Zeit“ 195(1977), nr 2, s. 129-135.

Kasper W., Zukunft aus dem Glauben, Mainz 1978.

Kasper W., Neuere philosophische Denkformen in der Theologie, „Münchener Theologische Zeitschrift“" 29(1978), s. 426-431.

Kasper W., Sein und Sendung des Priesters, „Geist und Leben“ 51(1978), nr 3, s. 196-212 .

Kasper W., Gottes Glaube im Angesicht von säkularisierter und atheistischer Umwelt, w: Ein Gott für die Welt. Glaube und Sinnfrage in unserer Zeit, red. H. Wieh, München 1980, s. 37-55.

Kasper W., Autonomie und Theonomie. Zur Ortsbestimmung des Christentums in der modernen Welt, „Theologisches Jahrbuch“ 1982, s. 172-197.

Kasper W., Jezus Chrystus, tłum. B. Białecki, Warszawa 1983.

Kasper W., Das kirchliche Amt in der Diskussion. Zur Auseinandersetzung mit E. Schillebeecks, „Das kirchliche Amt“, „Theologische Quartalschrift“ 163(1983), nr 1, s. 46-51 .

Kasper W., Das Glaubensbekenntnis der Kirche, „Internationale katholische Zeitschrift Communio“ 13(1984), nr 3, s. 255-271.

Kasper W., Die Weitergabe des Glaubens. Schwierigkeit und Notwendigkeit einer zeitgemäßen Glaubensvermittlung, w: Einführung in den Katholischen Erwachsenenkatechismus, red. W. Kasper, Düsseldorf 1985, s. 13-35.

Kasper W., Sie suchten die Wahrheit. Heilige Theologen, Mainz 1985.

Kasper W., Was alles Erkennen übersteigt, Freiburg 1987.

Kasper W., Gottes Zeit für die Menschen. Besinnung zum Kirchenjahr, Freiburg 1987.

Kasper W., Kirchenamt, w: Staatslexikon. Recht - Wirtschaft - Gesellschaft (hrsg. v. der Görres-Gesellschaft), t. 3 (1987), s. 413-416.

Kasper W., Zur gegenwärtigen Situation und zu den gegenwärtigen Aufgaben der systematischen Theologie, w: W. Kasper, Theologie und Kirche, Mainz 1987, s. 7-22.

Kasper W., Tradierung und Vermittlung als systematisch-theologisches Problem, w: Tradierungskrise des Glaubens, red. E. Feifel, W. Kasper, München 1987, s. 30-52.

Kasper W., Säkularisierung, w: Staatslexikon. Recht - Wirtschaft - Gesellschaft, t. 4 (1988), (hrsg. v. der Görres-Gesellschaft), s. 993-998.

Kasper W., Wahrheit und Freiheit: Die „Erklärung über die Religionsfreiheit“ des zweiten Vatikanischen Konzils, Heidelberg 1988.

Kasper W., Die Wissenschaftspraxis der Theologie, w: Handbuch der Fundamentaltheologie, red. W. Kern, H. J. Pottmeyer, M. Seckler, t. 4, Freiburg 1988, s. 242-277.

Kasper W., Hinführen zum Glauben - warum und wie?, „Internationale katholische Zeitschrift Communio“ 17(1988), nr 2, s. 97-103.

Kasper W., Kirche und neuzeitliche Freiheitsprozesse, w: Vernunft des Glaubens. Festschrift zum 60. Geburtstag von Wolfhart Pannenberg, red. J. Rohls, G. Wenz, Göttingen 1988, s. 593-610. 
Kasper W., Zur Lage der katholischen Kirche Deutschlands, „Internationale katholische Zeitschrift Communio“ 17(1988), nr 1, s. 64-72.

Kasper W., Zur Situation der katholischen Theologie in der Bundesrepublik Deutschland, w: Kirche in Europa, red. F. Wetter, Düsseldorf 1989, s. 65-75.

Kasper W., Natur-Gnade-Kultur. Zur Bedeutung der modernen Säkularisierung, ,Theologische Quartalschrift“"170(1990), nr 2, s. 81-97.

Kasper W., Die Weitergabe des Glaubens in Ehe und Familie. Hirtenbrief an die Gemeinden der Diözese Rottenburg-Stuttgart zur österlichen Bußzeit 1990, „Kirchliches Amtsblatt der Diözese Rottenburg-Stuttgart“ 41(1990), nr 5, 2. Februar 1990, s. 33-37.

Kasper W., Ansprache beim Empfang des Katholisch-Theologischen Fakultätentages (27 Januar 1991), „Theologische Quartalschrift“ 171(1991), nr 4, s. 247-250.

Kasper W., Gemeindeaufbau und Gemeindeleitung: Zentrale Perspektiven angesichts des Priestermangels (hrsg. vom Bischöflichen Ordinariat der Diözese Rottenburg-Stuttgart), Rottenburg 1991, s. 3-19.

Kasper W., Jesus der Christus, Mainz 1992.11, Vorwort zur elften Auflage (W. Kasper, J. Drumm), s. I-XXII.

Kasper W., Evangelisierung und Neuevangelisierung. Überlegungen zu einer neuen pastoralen Perspektive, w: Verantwortung für den Glauben: Beiträge zur Fundamentaltheologie und Ökumenik. Festschrift für H. Fries, red. P. Neuner, H. Wagner, Freiburg im Breisgau 1992, s. 231-244.

Kasper W., Einheit Europas in Wahrheit und Freiheit, ET, Bulletin 3(1992), s. 95-100.

Kasper W., Neuevangelisierung in Europa: Eine Anfrage an christliche Führungskräfte, „Land aktuell“ 44(1992), s. 199-202.

Kasper W., Ser cristiano en la Europa de los años 90, w: Cristianismo y cultura en la Europa de los años 90, red. W. Kasper, G. Amengual, J. Daniel i in., Madrid 1993, s. 9-27.

Kasper W., Europäisches Denken und christliche Botschaft, w: Aufklärung durch Tradition, red. H. Fechtrup, F. Schulze, T. Sternberg, Münster 1995, s. 109-122.

Kasper W., Kościót i wolność, tłum. J. Skupieńska, „Chrześcijanin w Świecie” 25(1995), nr 2, s. 25-41; oryg. franc.: L'Église et les processus modernes de la liberté, „La Documentation Catholique“ 77(1995), s. 238-245.

Kasper W., Bóg Jezusa Chrystusa, tłum. J. Tyrawa, Wrocław 1996.

Kasper W., Diener eurer Freude, „Berufung. Zur Pastoral der geistlichen Berufe“, z. 36, Freiburg 1998, s. 6-9.

Kasper W., Barmherzigkeit. Grundbegriff des Evangeliums - Schlüssel christlichen Lebens, Freiburg im Breisgau 2013.

Kasper W., Miłosierdzie. Klucz do chrześcijańskiego życia, thum. R. Zajączkowski, Poznań 2014.

Kongregacja Nauki Wiary, Instrukcja o chrześcijańskiej wolności $i$ wyzwoleniu (22.03.1986), w: W trosce o petnię wiary. Dokumenty Kongregacji Nauki Wiary 1966-1994, Tarnów 1995, s. 244-282.

Loewe W.P., The New Catholic Tübingen Theology of Walter Kasper: Foundational Issues, „Heythrop Journal” 21(1980), s. 30-49. 
Madonia N., Ermeneutica e cristologia in Walter Kasper, Palermo 1990.

Morawa J., Die Communio-Kirche als Sakrament des Heils in und für die Welt. Zum erneuerten Verständnis der Sendung der Kirche in der Gegenwart im Werk Walter Kaspers, Frankfurt a.M. 1996.

Napiórkowski S. C., Jak uprawiać teologię, Wrocław 1996.2.

Nichols A., Walter Kasper and His Theological Programme, „New Blackfriars” 1(1986), s. $16-24$.

Podhorecki N., Offenbarung - Schrift - Tradition. Walter Kaspers Beitrag zum Problem der Dogmenhermeneutik, Frankfurt am Main 2001.

Podhorecki N., Filozofia i teologia w interdyscyplinarnym dialogu, „Studia Sandomierskie" 12(2005), z. 2, s. 133-148.

Podhorecki N., Das Absolute in der Geschichte. Koncepcja Objawienia wedtug Waltera Kaspera, w: Objawienie Boże w interpretacji wspótczesnych teologów, red. B. Kochaniewicz, Studia Theogiae Fundamentalis, t. 1, Poznań 2010, s. 209-236.

Podhorecki N., Jezus Chrystus jako concretum universale w myśli teologicznej Waltera Kaspera, w: Jezus Chrystus w refleksji wspótczesnych teologów, red. B. Kochaniewicz, Colloquia Disputationes 21, Poznań 2013, s. 75-93.

Pröpper Th., Freiheit, w: Neues Handbuch theologischer Grundbegriffe, red. P. Eicher, t. 1, München 1984, s. 374-403.

Ratzinger J., Wiara - prawda - tolerancja. Chrześsijaństwo a religie świata, tłum. R. Zajączkowski, Kielce 2004.

Ratzinger J., Prawda w teologii, thum. M. Mijalska, Kraków 2005.

Theologie im Wandel. Festschrift zum 150jährigen Bestehen der katholisch-theologischen Fakultät an der Universität Tübingen 1817-1967, red. Ratzinger J., Neumann J., München 1967. 